\title{
Lise Öğrencilerinin Sosyal Medya Kullanım Alışkanlıkları ve Motivasyonları: Bir Saha Araştırması
}

\section{Özet}

İsmailcan DOĞAN*

Sanayi Devrimi'nden sonra yaşanan süreçte teknoloji hızla gelişmiş ve insanların etkileşimi, gelişen bu teknolojiyle paralel olarak artmıştır. Günümüzde, özellikle bilgisayar ve internet teknolojisinde yaşanan gelişmeler, bu etkileşimde başrol oynamaktadır. İnternetin sunduğu imkânlardan biri de hiç şüphesiz sosyal medyadır. Yapılan araştırmalar, insanların zamanlarının önemli bir kısmını sosyal medyada geçirdiğini göstermekle beraber, sosyal medyaya olan bu ilginin altında birçok istek, ihtiyaç ve motivasyonun da olduğunu ortaya çıkarmıştır. Bununla beraber sosyal medyanın kullanıcı kitlesinin önemli bir bölümünü lise çağındaki gençler oluşturmaktadır. Lise çağındaki gençlerin sosyal medyayı takip etmelerindeki amaç, motivasyon ve alışkanlıkları, ortaya çıkarılması gereken önemli bir meseledir. Buradan hareketle bu çalışmada öncelikle sosyal medya ile ilgili yerli ve yabancı literatürde yapılmış farklı çalışmalara değinilmiş, daha sonra ise lise öğrencileri örnekleminde sosyal medya kullanımının alışkanlık, amaç ve motivasyonları çerçevesinde bir saha araştırması yapılmışıır. Çalışmada veriler anket yöntemiyle Kayseri ili merkez ilçelerinden toplanmıştır. Bu kapsamda araştırma tabakalı örneklem yoluyla seçilen 1026 lise öğrencisi üzerinde yapılmıştır. Ortaya çıkan verilerin analizi neticesinde altı adet faktör belirlenmiştir. Bunlar sosyal kaçış, bilgilenme, boş zaman, ekonomik fayda, sosyal etkileşim ve eğlence faktörleridir. Bu faktörlerden sosyal kaçış faktörünün diğer faktörlere göre öne çıktığı görülmüştür. Ayrıca lise çağındaki erkek öğrencilerin sosyal medyada en fazla fotoğraf/video paylaşım sitelerini kullanırken, kadınların ise video paylaşım ve mesajlaşma/arama uygulamalarını daha fazla kullandıkları sonucu ortaya çıkmıştır.

Anahtar Kelimeler: Sosyal Medya, Lise Öğrencileri, Medya, Motivasyon, Yeni Medya

\section{High School Students' Social Media Usage Habits and Motivations: A Field Study}

Abstract

In the post Industrial Revolution period, technology developed rapidly and the interaction of people increased in line with the developing technology. Nowadays, advances in computer and internet technology, in particular, play a major role in this interaction. One of the facilities that the internet offers is undoubtedly social media. While the studies show that people spend a significant part of their time on social media, it has been revealed that there are many needs, desires, and motivations behind this interest in social media. However, young people of high school age are a significant part of the social media users. The purpose, motivation, and habits of high school-age youth in following social media is an important issue that needs to be revealed. Based on this, this study focused primarily on different studies conducted in domestic and foreign literature related to social media, and then a field study was conducted within the framework of the habits, goals, and motivations of using social media in a sample of high school students. The data of the study were collected from central districts of city of Kayseri through the survey method. In this context, the study was conducted with a total of 1026 high school students selected through stratified sampling. Six factors were identified as a result of the analysis of the resulting data. These are the factors of social escape, enlightenment, leisure, economic benefit, social interaction, and entertainment. From these factors, the social escape factor has been observed to stand out compared to other factors. Also, it was found that male high school students were found to mostly use photo/video sharing sites on social media, while females use video sharing and messaging/calling applications more.

Keywords: Social Media, High School Students, Media, Motivation, New Media

Geliş/Received: 12.11 .2020

Kabul/Accepted: 23.06 .2021

*Bu çalışma, Erciyes Üniversitesi Sosyal ve Beşeri Bilimler Etik Kurulu tarafından 10 numaralı başvuru ile 28.01.2020 tarihli toplantıda değerlendirilerek etik açıdan uygun bulunmuştur.

Dr. Öğr. Üyesi, Erciyes Üniversitesi İletişim Fakültesi Halkla İlişkiler ve Tanıtım Bölümü. ismailcandogan@erciyes.edu.tr ORCID ID: 0000-0001-9855-5159.

(Makale türü: Araştırma makalesi) 


\section{Giriş}

Geçmişten bu yana medya ile ilgili yapılan araştırmaların odak noktalarından birisi de etki araştırmalarıdır. Kitle iletişim kuramcılarının çoğu etki konusu ile ilgilenmiştir. Burada etkiler toplumdaki birçok grubun (gönderi ile diğerlerine ulaşmak isteyen, bu nedenle en etkili kanalı elde etmek isteyenler ve kitle iletişim araçlarının olumsuz etkilerinden endişe duyan grupların) ilgi odağı olmuştur (McQuail \& Windahl, 1997, s. 73). Kitle iletişim araçlarının izleyiciler üzerindeki etkileri söz konusu araçların ortaya çıkmasıyla beraber araştırılmaya başlanmıştır. Kimi araştırmalar araçların etkilerinin güçlü olmadığını savunurken (Işsk, 2005, s. 73), izleyicinin, aktif hale geldiğini savunan kullanımlar ve doyumlar yaklaşımı gibi yaklaşımlar “medya insanlara ne yapıyor?" sorusundan styrılarak "insanlar medya ile ne yapıyor?" sorusuyla konuya farklı bir açıdan yaklaşmışlardır. Kullanımlar ve doyumlar yaklaşımı ile izleyicinin aktif hale geçmesiyle bireyler medyanın etkisine direnç gösterebilen ve kendi arzularına yönelik olarak tercihte bulunan kişiler olarak kabul edilmiştir. Bu yaklaşım aynı zamanda bireylerin sosyal ve bireysel bazı ihtiyaçları bulunduğunu bize açıklamaktadır. Bireyler ihtiyaçlarını karşılama olanağı bulamadıklarında ise ihtiyaçlarını giderecek işlevi olan araçlara yönlenmektedirler. Gereksinimlerle olan yapıların farklılaşması ile insanların doyuma ulaşması iletişim araçlarını farklı şekilde kullanımıyla sonuçlanmıştır (Rosengren, 1974). Günümüzde geleneksel medyanın yanında yeni medya olarak adlandırılan internet teknolojilerinin bizlere sunduğu araçlardan birisi de sosyal medyadır. Sosyal medya kullanıcılara sunduğu birçok özellik ile her geçen gün yaygınlaşmaktadır. Kullanıcılara fotoğraf, video ve anlık durumlarının paylaşılmasına imkân sunan Instagram, Facebook gibi uygulamalar, kullanıcıların kendi kanallarını oluşturarak çektikleri videoları paylaşma imkânı sunan You Tube, fikir ve düşüncelerini twet adı verilen 280 karakterle sınırlı olan gönderilerle paylaşma imkânı sunan Twitter ve mesajlaşma ve aramayı bir arada kullanıcılarına sunan Watsapp gibi sosyal ağlar insanların hayatlarının vazgeçilmez bir parçası olmuş durumdadır.

$\mathrm{Bu}$ çalışma lise çağındaki gençlerin sosyal medya kullanım amaç ve motivasyonlarını ortaya çıkarma düşüncesinden hareketle yapılmıştır. Çalışmada yöntem olarak literatür taraması ve anket uygulaması kullanılmıştır. Bu kapsamda öncelikle sosyal medya konusunun literatürdeki durumu incelenmiş, daha sonra ise konuyla ilgili bir saha çalışmasına ve bu çalışmanın sonuçlarına yer verilmiştir.

\section{Literatür}

Günümüzde hızla geleneksel kitle iletişim araçlarının yerini alan internet, bugün çok sayıda kullanıcıya sahiptir. Özellikle geliştirilen sosyal medya teknolojisi ile kişiler arası 
iletişimde zaman ve mekân sınırlaması ortadan kalkmıştır. Böylece, kullanımı artan sosyal medya siteleri bireylerin kişisel ve sosyal yaşamlarını yoğun olarak etkilemeye başlamıştır. Bu olgu, sosyal medya bağımlılığının bireyin yaşamında ne çeşit sorunlara yol açtığı gerçeğine 1 şık tutmakta ve hatta bu sorunlara dair ipuçları vermektedir (Kıvanç, 2019, s. 96). Bu sorunların başında bireyin çevresiyle kurduğu iletişimin sekteye uğraması gelmektedir. Birey ailesiyle, arkadaşlarıyla yüz yüze iletişim kurmada zorluklar yaşamakta ve bölgesel iletişim azalmaktadır (Çetin, 2011, s. 158). 2019 yılında Türkiye İstatistik Kurumu tarafindan gerçekleştirilen Hanehalkı Bilişim Teknolojileri Kullanım Araştırması sonuçlarına göre ülkemizde hanelerin \%88,3'ünün evden İnternete erişim imkânına sahip olduğu gözlenmiştir. İnternet üzerinden kişisel kullanım amacıyla mal veya hizmet siparişi veren ya da satın alan 16-74 yaş grubundaki bireylerin oranı, 2018 yılı Nisan ayı ile 2019 yılı Mart aylarını kapsayan on iki aylık dönemde \%34,1 olarak ortaya çıkmıştır. Araştırma sonuçlarına göre internete erişimi olan haneler Türkiye genelinde internet kullanımı 16-74 yaş grubundaki bireylerde \%75,3 olmuştur. Bu oran bir önceki yı1 $\% 72,9$ 'du. Ayrıca araştırma sonuçları gençlerde internet kullanma oranının ise $\% 90,8$ olduğunu göstermektedir (Bkz. Grafik:1).

Grafik 1: Hanehalkı Bilişim Teknolojileri Kullanım Araştırması

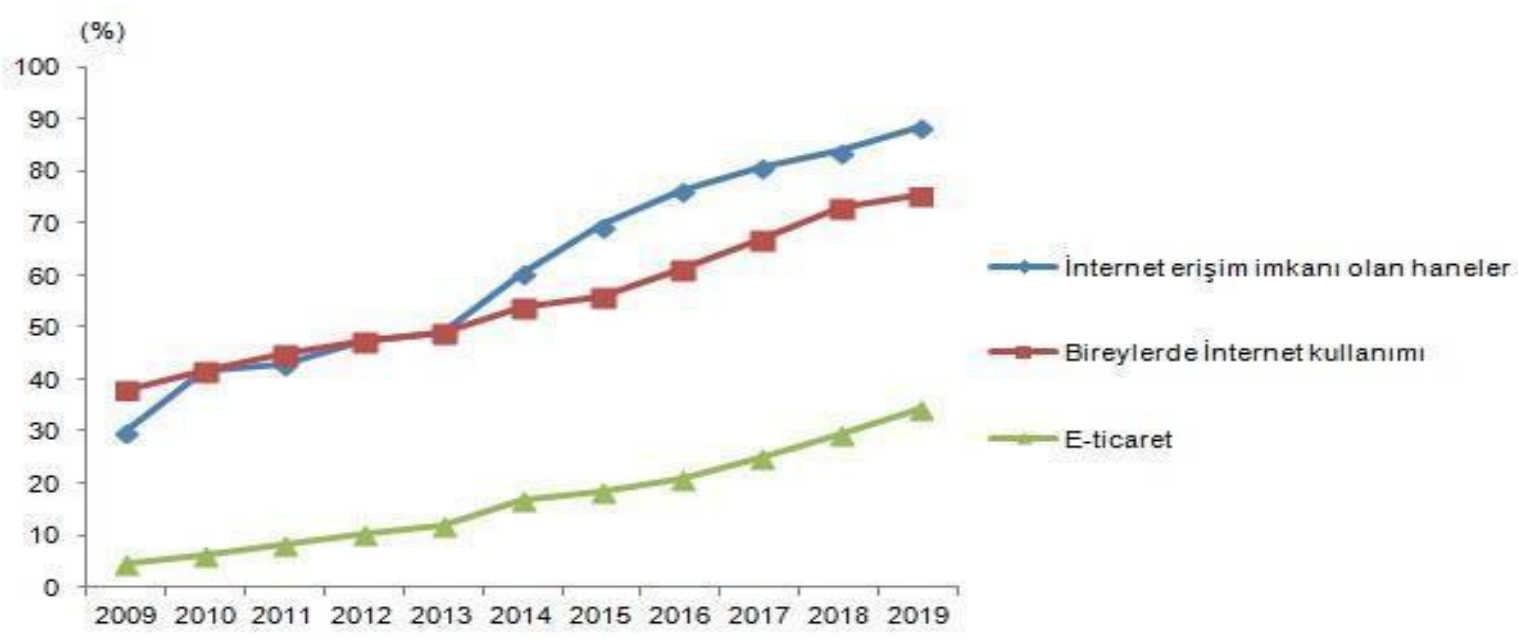

Kaynak: (TÜIK, 2019)

Görüldüğü gibi internet kullanımı her geçen yıl artmakta, internet gün geçtikçe hayatımızda daha fazla yer kaplamaktadır.

İnternetin bu hızla yayılmasının ve kullanılmasının sebepleri ile ilgili geçmişte ve günümüzde birçok araştırma yapılmıştır (Akar, 2015; Günlü \& Ceyhan, 2017; Satan, 2013; Okay, 2010; Ceyhan, 2011; Balcı ve Ayhan, 2007; Balay, Kaya, \& Çevik, 2014; Müezzin, 2017; Gökçearslan \& Seferoğlu, 2016; Topal \& Akgün, 2015; Alaca \& Tatl1, 2018; Aydın, 2016; Eşitti, 2015; Taylan \& Işık, 2015; Yolal \& Kozak, 2008; Y1lmaz \& Tümtürk, 2015; Göldağ, 2017; Özdemir \& Usta, 2007; Demir, Özköklü, \& Turğut, 2015). İnternetle ilgili bazı araştırmalar toplumdaki bireylerin internet bağımlılığını konu edinirken (Balc1, 2009; Satan, 2013; Usta, 2015; 
Ekşi \& Ümmet, 2013) bazıları ise internetin güvenilirliği üzerine yoğunlaşmıştır (Doğan \& Özkara, 2013; Aksoy, 2006; Sevim, 2018; Bayrakdaroğlu, 2012; Kalburan, Aydın, \& Haş1loğlu, 2018) Konuyla ilgili ülkemizde yapılan çalışmalar incelendiğinde literatürde genellikle üniversite öğrencilerine yönelik araştırmalar yapıldığı (Çemrek, Baykuş, \& Özaydın, 2014; Dağtaş \& Yıldırım, 2015; Toruk, 2008; Acun, Yücel, Belenkuyu, \& Keleş, 2017; Ustakara \& Türkoğlu, 2015; Aksoy \& Gür, 2018) görülmektedir.

Araştırmacıların gençlerle ilgili yapmış olduğu çalışmaları incelediğimizde birçok konuda araştırma yapıldığı görülmektedir. Araştırmacıların internet bağlamında araştırdığ konuların başında gençlerin oldukça ilgisini çeken dijital oyunlar gelmektedir. Dijital oyunların, dijital dünyanın içine doğan çocukların; boş zamanlarını değerlendirmek, eğitimlerine katkı sağlamak ve stres atmak gibi faydalı işlevlerinin yanında, içeriğinde barındırdığı şiddet, ırkçılık, cinsellik, toplumsal cinsiyet gibi olumsuz ögeleri normalleştirerek çocukların bilinçaltına yanlış kodlamalar yüklediği verilerini elde eden araştırmalar da mevcuttur (Açıkgöz \& Yalman, 2018; Evren, 2017; Göksu, Alan, \& Karakuş, 2016).

İnternet ile ilgili yapılan araştırmaların bir yönünü de sosyal medya oluşturmaktadır. Sosyal medya; insanları bir araya getiren, topluluklar oluşturulmasını sağlayan, kullanıcıların; üzerinde tartıştığı ve değiştirebileceği içerikler oluşturmasını ve oluşturdukları içerikleri birbirleriyle kolayca paylaşmalarını sağlayan etkileşimli web aracı olarak tanımlanabilir (Kietzmann, Hermkens, Mccarthy, \& Silvestre, 2011). İçeriği çok geniş olan sosyal ağlar, medya paylaşım servisleri, dosya paylaşım servisleri, canlı iletişim servisleri, iş birliğine dayalı servisler ve blog ya da "mikro blog" servisleri genel olarak sosyal medyanın çerçevesini oluşturur (Bkz. Tablo 1). Sosyal medya üzerinde yapılan araştırmalara bakıldığında ise sosyal medyaya birçok açıdan yaklaşan araştırmaların olduğu görülmüştür. Sosyal medya ve reklam arasındaki ilişkiyi açıklamaya çalışan araştırmalar: (Atar \& İspir, 2019; Girgin, 2016; Sabuncuoğlu \& Gülay, 2014; Tuzcu, Özdemir, \& Baysal, 2018; Süar, 2017; Aksoy \& Gür, 2018; Kıyan \& Dikmen, 2019; Albayrak, 2019; Oktuğ, 2013; Özgezmez \& Denktaş, 2017; Kayapınar, Kayapınar, \& Tan, 2017; Laman \& Topçu, 2019); sosyal medyanın pazarlama konusunda sahip olduğu gücü ortaya çıkarmayı amaçlayan çalışmalar: (Akgün \& Ergün, 2017; Onurlubaş, Öztürk, \& Çetin, 2016; Şahin \& Dündar, 2019; Keskin \& Baş, 2015; Erişke, Kabadayı, \& Alan,, 2018; Uyanık \& Yükselen, 2019; Çelik, 2014; Tuğrul, Doğan, \& Çavuşoğlu, 2017; Alyakut, 2017; Emirza, İştahl1, \& İştahl1,, 2012; Barutçu \& Tomaş, 2013; Öze, 2017; Çifci \& Sözen, 2017; Can, 2017; Torun, 2017; Bilgin, 2018; Alan, Kabaday1, \& Uzunburun, 2018; Aytan \& Eser, 2014; Erol, 2017; Çakırkaya \& Koçyiğit, 2019; Aycı, 2018; Gümüş \& Kütahyalı, 2017) karşımıza çıkmaktadır. 
Tablo 1: Sosyal Medya Sinıflandırılması

\begin{tabular}{|c|c|c|c|c|c|}
\hline Sosyal Ağlar & $\begin{array}{l}\text { Medya Paylaşım } \\
\text { Servisleri }\end{array}$ & $\begin{array}{l}\text { Dosya Paylaşım } \\
\text { Servisleri }\end{array}$ & $\begin{array}{l}\text { Canlı Illetişim } \\
\text { Servisleri }\end{array}$ & $\begin{array}{l}\text { İşbirliğine Dayalı } \\
\text { Servisler }\end{array}$ & $\begin{array}{l}\text { Blog ve Micro Blog } \\
\text { Servisleri }\end{array}$ \\
\hline $\begin{array}{l}\text { Bireysel profil } \\
\text { oluşturup benzer ilgi } \\
\text { alanlarındaki bireyler } \\
\text { ve arkadaşlar ile } \\
\text { bağlantıya geçme ve } \\
\text { bağlantıda olunan } \\
\text { kişilerle bilgi ve } \\
\text { düşünceleri paylaşma } \\
\text { olanağı sağlayan } \\
\text { ortamlar }\end{array}$ & $\begin{array}{l}\text { Ses, video, fotoğraf } \\
\text { gibi farklı medya } \\
\text { türlerini yükleme ve } \\
\text { paylaşma, aynı } \\
\text { zamanda animasyon } \\
\text { ve simülasyon } \\
\text { hazırlama ve } \\
\text { paylaşma olanağı } \\
\text { sağlayan ortamlar }\end{array}$ & $\begin{array}{l}\text { Farklı biçimlerdeki } \\
\text { dosyaları yükleme } \\
\text { ve paylaşma } \\
\text { olanağı sağlayan } \\
\text { ortamlar }\end{array}$ & $\begin{array}{l}\text { Canlı sesli ve } \\
\text { görüntülü iletişim } \\
\text { olanağı sağlayan } \\
\text { ortamlar }\end{array}$ & $\begin{array}{l}\text { Grup şeklinde ve } \\
\text { işbirliğine dayalı } \\
\text { çalışmaların ortaklaşa } \\
\text { yürütülmesine olanağı } \\
\text { sağlayan ortamlar }\end{array}$ & $\begin{array}{l}\text { Belirli bir temaya } \\
\text { odaklanarak süreli } \\
\text { yayınların } \\
\text { yapılmasına ya da } \\
\text { tartışmaların } \\
\text { yürütülmesine } \\
\text { olanağı sağlayan } \\
\text { ortamlar }\end{array}$ \\
\hline $\begin{array}{l}\text { Facebook } \\
\text { Google+ } \\
\text { Linkedln }\end{array}$ & $\begin{array}{l}\text { Youtube/Vimeo } \\
\text { Flickr/Picasa } \\
\text { Pinterest } \\
\text { Glogster } \\
\text { Animoto/goAnimate/ } \\
\text { Xtranormal }\end{array}$ & $\begin{array}{l}\text { Slideshare } \\
\text { Prezi } \\
\text { Dropbox } \\
\text { Google Drive } \\
\text { Webspiration } \\
\text { Ustream }\end{array}$ & $\begin{array}{l}\text { Hangout } \\
\text { Skype } \\
\text { Viber } \\
\text { Dimdim }\end{array}$ & $\begin{array}{l}\text { Wiki } \\
\text { Google Drive } \\
\text { Zoho }\end{array}$ & $\begin{array}{l}\text { Tumblr } \\
\text { Edublogs } \\
\text { Twitter } \\
\text { Wordpress } \\
\text { Blogger } \\
\text { Scoop.it }\end{array}$ \\
\hline
\end{tabular}

Kaynak: (Güven, 2010)

Konuyla ilgili bir başka araştırma ise sosyal medya ve siyasal iletişimdir. Sosyal medyanın siyasal amaçlı kullanımı, seçim kampanyalarındaki kullanımı, kamuoyu ölçme aracı olarak kullanımı, kamu kurumlarının sosyal medyayı kullanma durumları gibi araştırma alanları başta olmak üzere sosyal medya ve siyasal iletişim konusu araştırmacılar tarafından irdelenmiştir (Arklan, 2016; Aksoy, 2015; Göksu, 2018; Toker, Erdem, \& Özşarlak, 2017; Onat ve Okmeydan, 2015; Erkek, 2016; Çağlar \& Köklü, 2017; Metin, 2016; Erkan \& Ayhan, 2018; Şener, Öğün, \& Akyıldız, 2015). Sosyal medya eleştirel bakış açısı ile de tartışılmışıı. Sosyal medyanın kültür endüstrisinin oluşmasındaki rolü, lüks tüketim alışkanlıklarındaki rolü, bireylerin tüketim nesnesine dönüşmesindeki etkisi eleştirel bir bakış açısıyla literatürde tartışılmıştır (Güzel, 2016; Öze, 2017; Çelik, 2016). Sosyal medya üzerinde araştırmalar yapılan alanlardan biri de halkla ilişkiler alanıdır. Literatürde genelde konuya kurumsal açıdan yaklaşan çalışmalara rastlanmıştır. Sosyal Medyanın Kriz Yönetimindeki Rolü (Duğan, 2018), Halkla İlişkiler Alanı Olarak Sosyal Medya Kullanımı (Onat, 2010), Sosyal Medyanın Tanıtımdaki Rolü (Akar, 2015), Kurumsal İmaj Bağlamında Sosyal Medyanın Rolü (Kartal \& Algül, 2019), Kurumsal İtibarın Sosyal Medya Üzerinden Aktarımı (Tokatlı, Özbükerci, Günay, \& Vural, 2017) gibi çalışmalar literatürde öne çıkmaktadır. Sosyal medya konusunda eğitim-öğretim alanında yapılan çalışmalar, öğretme ve öğrenmede sosyal medyanın rolü (Sarsar, Başbay, \& Başbay, 2015), öğretmen ve öğretmen adaylarının sosyal medya kullanım amaç ve motivasyonları (Alakurt, 2016), (Söylemez \& Oral, 2018), öğretmenlerin sosyal medya bağımlılı̆̆ı (Döş \& Özşahin, 2019), sosyal medya okuryazarlığı (Kartal, Yazgan, \& Kıncal, 2017) ve yardım kuruluşlarının sosyal medya kullanımı (Altıncık \& Yaşar, 2017) gibi eksenlerde konu tartış1lmıştır.

Sosyal medya konusunda uluslararası literatür incelendiğinde de yabancı araştırmacıların bu konuya ciddi şekilde kafa yordukları görülmektedir. Global olarak sosyal medyanın yararları 
ve zararları (Bennet, 2014), Sosyal Medya ve Popüler Kültür İlişkisi (Givens-Carroll, Narro, \& Slade, 2015; Mcclain, 2013; Abidin, 2018; Prorokova \& Tal, 2018); Sosyal Medyada İmaj Oluşturma (Ordenes, ve diğerleri, 2019), Sosyal Medya ve Tüketici Davranışları (Grewal, Stephen, \& Coleman, 2019), Sosyal Medyanın Sosyalleşme Üzerindeki Etkisi (Biszko, 2019), Sosyal Medyanın Lisans Öğrencileri Üzerindeki Faydaları ve Zararları (Emerick, Caldarella, \& Black, 2019), Sosyal Medyada İçerik Oluşturma (Kanuri, Chen, \& Sridhar, 2018), Sosyal Medyada Örgütsel İtibarın Oluşumu (Etter, Ravasi, \& Colleoni, 2019), Sosyal Medya Reklamc1lığı (Voorveld, Van Noort, Muntinga, \& Bronner, 2018; Johnston, Khalil,, Le, \& MingSung Cheng, 2018), Sosyal Medya Kullanımı İçin Gerekenler (Karahanna, Xu, Xu, \& Zhang, 2018), Sosyal Medyanın Marka Oluşturmadaki Rolü (Kupfer, Vor Der Holte, Kübler, \& HennigThurau, 2018; Gao, Tate, Zhang, Chen, \& Liang, 2018; Scholz \& Smith, 2019); Sosyal Medyada Bilgi Edinme (Marley \& Snow, 2019) çalışmalarına literatürde karşılaştığımız çalışmalar olarak değinmemiz gerekir. Öte yandan bu araştırmayla bağlantılı olarak sosyal medyanın gençler üzerindeki rolüne yönelik yapılmış çalışmalar yabancı literatürde önemli bir yer tutmaktadır.

Yabancı literatürde sosyal medyanın lise çağındaki gençler üzerindeki etkileri; sosyalleşme ve sosyal bilinç oluşturmadaki rolü (Sangeetha \& Vanitha, 2019), sosyal medyayı kullanım sıklıkları (Shafi, ve diğerleri, 2019), sosyal medyaya yönelik tutumları (Asare-Donkoh, 2018) çerçevesinde araştırıldığ görülmüştür.

Tüm bu literatür değerlendirildiğinde farklı perspektiflerden konuyu ele alan bu çalışmalar konunun önemine işaret etmektedir. Günümüzde insan hayatının önemli bir parçası haline gelen sosyal medya uygulamaları kurumsal iletişimden popüler kültüre, reklamcılıktan pazarlamaya kadar çok geniş bir yelpazede etkisini hissettirmektedir. Bireyler üzerindeki etkileri ise özellikle genç bireyler bağlamında değerlendirildiğinde üzerinde durulması gereken önemli bir konudur. $\mathrm{Bu}$ nedenle lise çağındaki bireylerin sosyal medya kullanım alışkanlıkları ve motivasyonları sosyal, kültürel, sosyolojik, psikolojik birçok yönden ele alınması ve araştırılması gereken çok yönlü bir meseledir. Yapılan araştırmalar incelendiğinde konunun genellikle sosyal bağlamda ele alındığı görülmektedir.

\section{Konunun Amacı ve Önemi}

$\mathrm{Bu}$ araştırma lise çağındaki gençlerin sosyal medyayı takip etmelerindeki amaç, motivasyon ve alışkanlıkları üzerine yoğunlaşarak sosyal medyanın lise çağındaki genç bireyler üzerindeki olumlu veya olumsuz etkilerinin üzerinde yoğunlaşan tartışmalara ampirik verilerle katkı sunmayı hedeflemektedir. Bu bağlamda araştırma soruları şunlardır:

Araştırma Sorusu 1: Lise çağındaki gençlerin sosyal medya kullanma davranışları, tercihleri ve alışkanlıkları nelerdir? 
Araştırma Sorusu 2: Lise çağındaki gençlerin sosyal medyayı takip etme motivasyonları nelerdir? Araştırma Sorusu 3: Lise çağındaki gençlerin sosyal medyayı kullanma sıklıkları nedir? Araştırma Sorusu 4: Lise çă̆ındaki gençlerin sosyal medyayı kullanma motivasyonları nelerdir? Araştırma Sorusu 5: Lise çağındaki gençlerin sosyal medyada en sık takip ettikleri hesaplar kimlerdir?

Yukarıdaki araştırma soruları göz önünde tutularak çalışmada, lise çağındaki gençlerin sosyal medyayı kullanım davranışlarının ve motivasyonlarının ortaya konulması amaçlanmaktadır.

\section{Araștırmanın Modeli}

Lise öğrencilerinin sosyal medya kullanım alışkanlıkları ve motivasyonları başlıklı bu çalışma; nicel verilere dayalı, betimleyici ve keşfedici bir alan araştırması olarak tasarlanmış ve gerçekleştirilmiştir. Bu amaçla lise çağındaki gençler ve sosyal medya olarak belirlenen konu sınırlandırılarak lise çağındaki gençlerin sosyal medya kullanım alışkanlıkları ve motivasyonları üzerine odaklanılmıştır.

\section{Araştırmanın Sınırlılıkları}

Çalışmanın başlıca sınırlılıkları şu şekildedir:

-Araştırmamız lise çağındaki öğrenciler üzerinde yapılmıştır. Bu nedenle 14-18 yaşlarındaki lise öğrencileri çalışmanın temel sınırlılıklarından biridir.

- Çalışmanın bir diğer sınırlılığı araştırmada evrene tamamen ulaşmak mümkün olmadığından dolayı Kayseri ili merkez ilçelerinde yapılmış olmasıdır. Dolayısıyla çalışma Kayseri ilinin merkez ilçeleri ile sınırlıdır.

-Veri toplama aracı olarak anket tekniği kullanımı ise bir başka çalışmanın bir diğer sınırlılığıdır.

\section{Evren ve Örneklem}

Çalışmanın evreni Kayseri ili sınırları içerisinde eğitim gören lise öğrencileridir. Dolayısıyla çalışmanın örneklemi araştırmanın gerçekleştirildiği Kayseri ilinden seçilmiştir. Kayseri nüfusu göz önüne alındığında örneklem büyüklüğü 660 olarak belirlenmiştir. Kayseri Valiliğinden alınan verilere göre Kayseri ilinde özel ve resmî olmak üzere 214 lise bulunmaktadır. Bu kurumlarda 41201 kız öğrenci ve 39891 erkek öğrenci eğitim görmektedir. Toplam öğrenci sayısı ise 81092'dir (kayseri.gov.tr). Çalışma kapsamında yapılan alan araştırması için evrenimiz Kayseri merkez ilçelerinde eğitim gören lise öğrencileri olarak belirlenmiştir. Örneklemimiz ise \%99 güven düzeyi ile Kayseri ili merkez ilçelerinden orantılı bir biçimde seçilecek olan 1000 lise öğrencisi olarak belirlenmiştir. Araştırmada tabakalı örneklem tekniği kullanılmıştır. Lise eğitimi gören 9, 10, 11 ve 12. sınıf öğrencileri için tabakalı bir örneklem hesaplaması yapılarak orantılı bir şekilde örneklem seçimi yapılmıştır. Anketlerin yüz yüze yapılması planlanmış ancak Covid19 salgını nedeni ile online olarak uygulanmıştır. Toplamda 1026 lise öğrencisine anket uygulanmış ve toplanan veriler analiz edilmiştir.

\section{Veri Toplama Aracı}


Ulaşılan örneklemden veriler hazırlanan soru formu aracılığı ile toplanmıştır. Soru formu oluşturulurken Balcı ve Ayhan'ın (2007) Üniversite Öğrencilerinin İnternet Kullanım ve Doyumları Üzerine Bir Saha Araştırması isimli çalışmasında kullanılan ölçekten faydalanılmıştır. Araştırma kapsamında uygulanan soru formu 4 bölümden oluşmuştur. Birinci bölümde gençlerin boş zamanlarını nasıl değerlendirdikleri ve yaptıkları aktiviteler ile ilgili sorular yöneltilmiştir. İkinci bölümde sosyal medya araçlarını takip etme alışkanlıklarını ortaya koyacak sorular sorulmuştur. Hangi sosyal medya aracını daha çok takip ettiği, ne sıklıkla kullandığı, takip ettiği içeriklerin çeşidi ile ilgili sorular yönetilmiştir. Üçüncü bölümde ise sosyal medya kullanım ve motivasyonlarını ölçmek amaçlı sorular sorulmuştur. Buraya kadar sorulan sorular 5'li likert ölçek tipine göre uygulanmıştır. Son bölümde ise sosyo-demografik özelliklerin ortaya çıkarılmasına yönelik sorular yer almıştır.

Araştırma kapsamında oluşturulan soru formu farklı meslektaşların incelemesine tabi tutulmuş, verilen öneriler 1şı̆̆ı̆nda değişiklikler yapılmıştır. Ayrıca soru formu 50 lise öğrencisi üzerinde ön teste tabi tutulmuş ve istatistiki analizler gerçekleştirilerek eksiklikler giderilmiştir.

\section{Verilerin İşlenmesi ve Analizi}

Toplanan verilerin analizi SPSS 22 istatistik paket programında yapılımıștır. Analizlerde frekans dağılımları ile çapraz tablolar (cross-tabulation) gibi betimleyici istatistik teknikleri ve ortalama, ortanca, en düşük, en yüksek değer gibi merkezî eğilim ölçüleri kullanılmıştır. Çıkarımcı istatistikler olarak ise, değişkenler arası ilişkileri görmek için 2 kategorili değişkenlerde bağımsız değişkenli t-test analizleri uygulanmıştır. İlişkili olan ve olmayan değişkenlerle ilgili sonuçlarla birlikte ayrıntılı tablolara yer verilmiştir. Ayrıca faktör analizi yapılarak lise öğrencilerinin sosyal medya kullanım amaç ve motivasyonlarının faktörleri ortaya çıkarılmıştır.

\section{Etik Beyan}

Bu çalışma Erciyes Üniversitesi Sosyal ve Beşerî Bilimler Etik Kurulu 28/01/2020 tarihli, 10 başvuru no.lu kararı çerçevesinde çalışma etik açıdan bir sakınca içermemektedir.

\section{Bulgular}

Öncelikle araştırma kapsamında katılımcılara yöneltilen ölçek maddelerin genel güvenilirlik analizi sonucuna bakıldığı zaman Chronbach's Alpha değerinin 0,95 olarak ortaya çıtı̆̆g görülmüştür. Ortaya çıkan bu değer ölçeğin yüksek güvenilirlikte olduğunu göstermektedir $(0,80<0,95<1,00)$.

Tablo 2: Katılımcıların Demografik Özellikleri

\begin{tabular}{llll}
\hline & & Sayı & Yüzde \\
\hline \multirow{2}{*}{ Cinsiyet } & Erkek & 433 & $\% 42,2$ \\
& Kadın & 592 & $\% 57,8$
\end{tabular}




\begin{tabular}{|c|c|c|c|}
\hline \multirow{4}{*}{ Gelir } & Cevapsız & 16 & $\% 1,6$ \\
\hline & 1000 TL alt1 & 48 & $\% 4,7$ \\
\hline & $\begin{array}{l}1001 \mathrm{TL}-2500 \mathrm{TL} \\
\operatorname{aras1}\end{array}$ & 305 & $\% 29,8$ \\
\hline & $\begin{array}{l}2501 \mathrm{TL}-3500 \mathrm{TL} \\
\operatorname{aras1}\end{array}$ & 323 & $\% 31,5$ \\
\hline \multirow{6}{*}{ Sinıf } & $\begin{array}{l}3501 \mathrm{TL}-5000 \mathrm{TL} \\
\operatorname{aras1}\end{array}$ & 197 & $\% 19,2$ \\
\hline & $\begin{array}{lll}5001- & 6000 & \mathrm{TL} \\
\text { aras1 } & & \\
\end{array}$ & 62 & $\% 6,0$ \\
\hline & 6001 TL üzeri & 74 & $\% 7,2$ \\
\hline & 9. $\sin 1 f$ & 280 & $\% 27,3$ \\
\hline & 10. sinif & 268 & $\% 26,2$ \\
\hline & 11. sinif & 243 & $\% 23,7$ \\
\hline \multirow{7}{*}{ Yaş } & 12. sinif & 233 & $\% 22,8$ \\
\hline & 13 & 37 & $\% 3,6$ \\
\hline & 14 & 186 & $\% 18,1$ \\
\hline & 15 & 261 & $\% 25,5$ \\
\hline & 16 & 251 & $\% 24,5$ \\
\hline & 17 & 227 & $\% 22,1$ \\
\hline & 18 & 63 & $\% 6,1$ \\
\hline
\end{tabular}

Araştırmamıza katılanların demografik özellikleri incelendiği zaman ortaya çıkan sonuçlar şu şekildedir: Katılımcıların \%42,8'i erkek, \%57,8'i ise kadındır. Araştırmamıza katılan deneklerin ailelerinin gelir durumları incelendiğinde; \%4,7'si 1000 TL altı gelir düzeyine sahip, \%29,8'i 1001 TL- 2500 TL aras1 gelir düzeyine sahip, \%31,5'i 2501 TL- 3500 TL aras1 gelir düzeyine sahip, \%19,2'si 3501 TL- 5000 TL arası gelir düzeyine sahip, \%7,2'lik bir kesim ise 6001 TL üzeri gelir düzeyine sahiptirler. Katılımcıların eğitim gördükleri sınıfın düzeyi incelendiğinde; \%27,3'ünün 9. sınıf öğrencisi, \%26,2'sinin 10. sınıf öğrencisi, \%23,7’sinin 11. sınıf öğrencisi, \%22,8'inin ise 12. sınıf öğrencisidir. Son olarak katılımcıların yaşları incelendiğinde ise; \%3,6'nın 13 yaşında, \%18, '1' in 14 yaşında, \%25,5'in 15 yaşında, \%24,5'in 16 yaşında $\% 22,1$ 'in 17 yaşında ve $\% 6,1$ 'in ise 18 yaşındadır.

Tablo 3: Sosyal Medya Araçları Kullanım Sıklıkları Betimleyici İstatistikleri

\begin{tabular}{llllll}
\hline & Say1 & En Düşük & En Yüksek & Ortalama & SD \\
\hline Whatsapp & 1025 & 1,00 & 5,00 & 3,9141 & 1,07277 \\
YouTube & 1025 & 1,00 & 5,00 & 3,6459 &, 99728 \\
Instagram & 1025 & 1,00 & 5,00 & 3,3844 & 1,34286 \\
Twitter & 1025 & 1,00 & 5,00 & 1,5600 & 1,04888 \\
Facebook & 1025 & 1,00 & 5,00 & 1,3932 &, 81403 \\
Diğer & 1025 & 1,00 & 5,00 & 1,9073 & 1,25242 \\
Geçerli Sayı & 1025 & & & & \\
\hline
\end{tabular}

Araştırmamız kapsamında sosyal medya araçlarını kullanım sıklıklarını ortaya çıkarmak için katılımcılara yöneltilen soruya verilen cevapların ortalamaları Tablo-3'te görülmektedir. Buna göre ortaya çıkan veriler şu şekildedir: Lise öğrencilerinin en fazla kullandıkları sosyal medya aracı bir metin ve sesli mesaj uygulaması olan Whatsapp olarak ortaya çıkmıştır. Bu aracı kullanım ortalaması 3,9141'dir. İkinci sırada ise bir video paylaşım sitesi olan YouTube 
gelmektedir. Bu aracın kullanım ortalaması 3,6459 olarak ortaya çıkmıştır. Üçüncü sırada 3,3844 ortalama ile bir fotoğraf ve video paylaşım sitesi olan Instagram gelmektedir. Lise öğrencilerinin daha az kullandıkları sosyal medya araçları ise 1,5600 ortalama ile gönderi paylaşım sitesi olan Twitter ve 1,3932 ortalama ile sosyal paylaşım sitesi olan Facebook olarak sıralanmıştır. Öte yandan diğer seçeneğinin ortalamasının ise 1,9073 olduğu görülmektedir. Ortaya çıkan bu sonuçlar, ortalaması 3,00'ün üstünde olan Whatsapp, Youtube ve Instagram'ın lise çağındaki gençlerin en fazla kullandıkları sosyal medya araçları olduğunu göstermektedir.

Tablo 4: Cinsiyet İtibarıyla Sosyal Medya Araçları Kullanım Sıklıkları

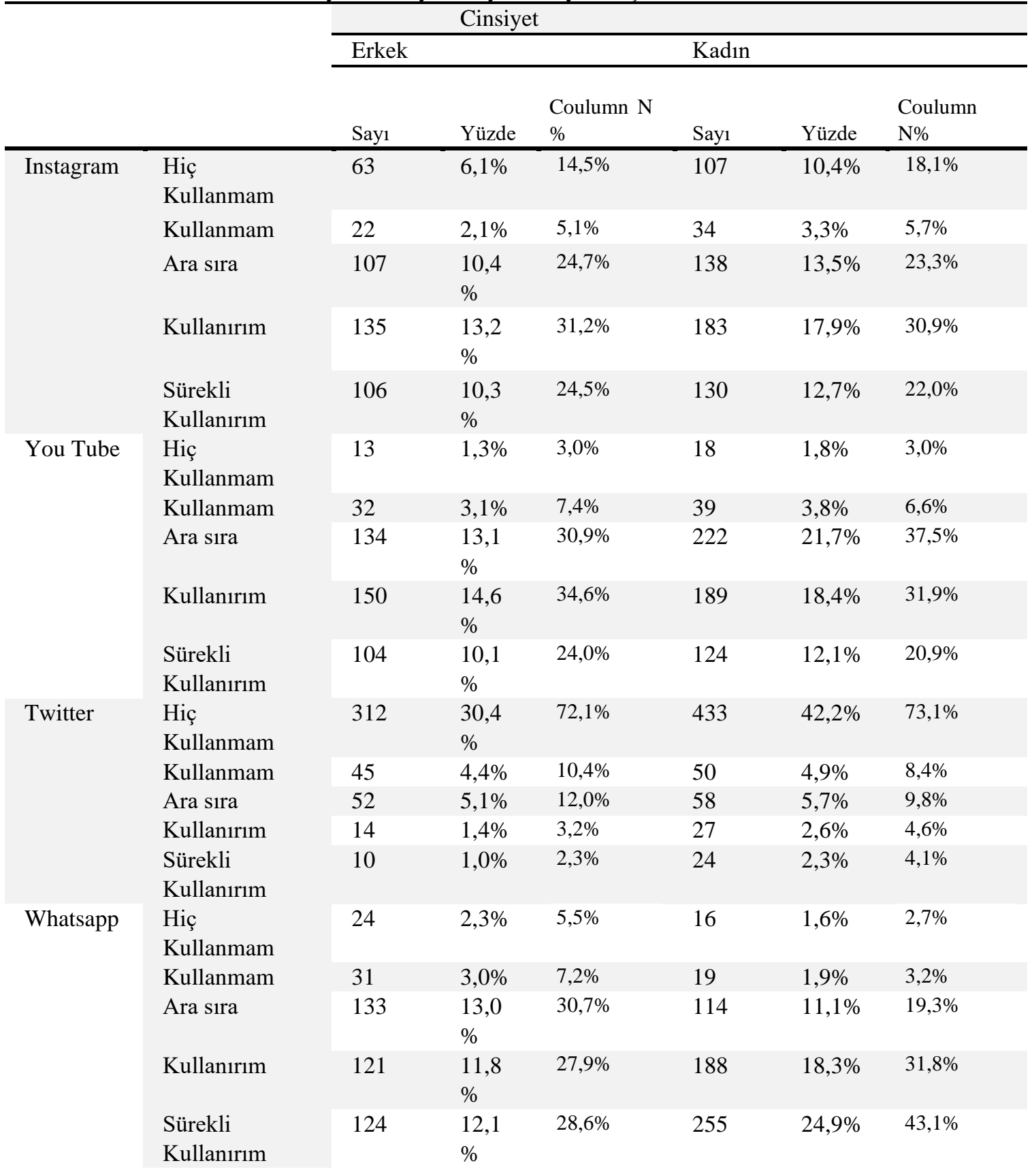




\begin{tabular}{llllllll} 
Facebook & Hiç & 271 & 26,4 & $62,6 \%$ & 517 & $50,4 \%$ & $87,3 \%$ \\
& Kullanmam & & $\%$ & & & & \\
& Kullanmam & 71 & $6,9 \%$ & $16,4 \%$ & 43 & $4,2 \%$ & $7,3 \%$ \\
Ara sıra & 64 & $6,2 \%$ & $14,8 \%$ & 24 & $2,3 \%$ & $4,1 \%$ \\
Kullanırım & 23 & $2,2 \%$ & $5,3 \%$ & 4 & $0,4 \%$ & $0,7 \%$ \\
Sürekli & 4 & $0,4 \%$ & $0,9 \%$ & 4 & $0,4 \%$ & $0,7 \%$ \\
Kullanırım & & & & & & \\
\hline
\end{tabular}

Katılımcıların cinsiyetleri itibarıyla sosyal medya araçlarını kullanım sıklıkları Tablo 4'te sunulmuştur. Tablo 4'te öncelikle fotoğraf ve video paylaşım sitesi olan Instagram aracına baktığımız zaman; erkeklerin \%80,5'i “Çeşitli düzeylerde Instagram kullanırım” derken bu oran kadınlarda \%76,2 olarak ortaya çıkmıştır. Video paylaşım sitesi YouTube'a bakıldığında ise erkeklerin \%89,5'i YouTube'u çeşitli düzeylerde kullandığını belirtirken bu oran kadınlarda \%90,3 olmuştur. Twitter'da erkeklerin sadece \%17,5'i, kadınların ise 18,5'i çeşitli düzeylerde Twitter kullandığını ifade etmişlerdir. Mesajlaşma uygulaması olan Whatsapp'a baktığımızda erkeklerin \%87,2'si kadınların ise \%94,2'si çeşitli düzeylerde bu aracı kullandıklarını belirtmişlerdir. Son olarak Facebook aracını erkeklerin \%21'i, kadınların ise \%5,5'inin çeşitli düzeylerde kullandıkları görülmüştür.

$\mathrm{Bu}$ sonuçlar Instagram ve Facebook'u erkeklerin kadınlardan daha fazla kullandığını, YouTube, Twitter ve Whatsapp'ı ise kadınların erkeklerden daha fazla kullandığını göstermektedir.

Tablo 5: Sosyal Medyada Geçirilen Süre

\begin{tabular}{lcc}
\hline & Sayı & Geçerli Yüzde \\
\hline 1-2 saat & 412 & 40,2 \\
3-4 saat & 382 & 37,3 \\
5-6 saat & 152 & 14,8 \\
$7-8$ saat & 41 & 4,0 \\
8 saatten fazla & 38 & 3,7 \\
Toplam & 1025 & 100,0 \\
\hline
\end{tabular}

Lise öğrencilerinin sosyal medyada ortalama kaç saat geçirdiklerini tespit etmek için yöneltilen soruya katılımcıların verdikleri cevaplar Tablo 5'te görülmektedir. Sonuçlar incelendiğinde lise öğrencilerinin \%40,2' lik kesimi ortalama 1-2 saat, \%37,3’ü ortalama 3-4 saat, $\% 14,8$ 'i ortalama 5-6 saat, \%4'ü ortalama 7-8 saat ve \%3,7'si ise 8 saatten fazla sosyal medyada zaman geçirmektedir.

Tablo 6: Paylaşım Yapma Sıklı̆̆1

\begin{tabular}{lll}
\hline & Sayı & Geçerli Yüzde \\
\hline Saatte en az 1 paylaşım & 15 & 1,5 \\
Günde en az 1 paylaşım & 21 & 2,0 \\
Haftada en az 1 paylaşım & 61 & 6,0 \\
Ne zaman denk gelirse & 928 & 90,5 \\
Toplam & 1025 & 100,0 \\
\hline
\end{tabular}

Lise öğrencilerinin sosyal medyada paylaşım yapma sıklıklarını ortaya koymak için yöneltilen soruya verilen cevaplar Tablo 6' da görülmektedir. Ortaya çıkan sonuçlar şu şekildedir: 
Katılımcıların \%1,5'i saatte en az 1 paylaşım, \%2'si günde en az 1 paylaşım, \%6'sı haftada en az bir paylaşım yaptığını belirtmişlerdir. Katılımcıların büyük çoğunluğunu oluşturan \%990,5'lik kesim ise ne zaman denk gelirse paylaşım yaparım seçeneğini tercih etmişlerdir.

Tablo 7: Sosyal Medyada En Fazla Takip Edilenler

\begin{tabular}{lcl}
\hline & Sayı & Geçerli Yüzde \\
\hline Aile & 771 & 75,2 \\
Akrabalar & 675 & 65,9 \\
Arkadaşlar & 919 & 89,7 \\
Fenomenler & 447 & 46,5 \\
Öğretmenler & 297 & 29 \\
Siyasiler & 121 & 11,8 \\
Din Adamları & 73 & 7,1 \\
Toplam & $3303^{*}$ & \\
\hline
\end{tabular}

*Bu soruda çoklu yanıt olduğundan dolayı $N$ sayısı örneklem saylsını geçmektedir.

Katılımcıların sosyal medyada takip ettikleri kişi ya da kişilerle ilgili yapılan analiz sonucu Tablo 7'de görülmektedir. Tablo 7'de ortaya çıkan sonuçlara göre bu soruya cevap veren lise çağındaki öğrencilerin \%75,2'si ailesini, \%65,9 akrabalarını, \%89,7 arkadaşlarını, \%46,5'i fenomenleri, \%29'u öğretmenlerini, \%11,8'i siyasileri ve son olarak \%7,1'i ise din adamlarını takip ettiklerini belirtmişlerdir. Ortaya çıkan sonuçlara göre lise çağındaki gençlerin en fazla arkadaşlarını takip ettikleri görülürken bunu ailesi, akrabaları ve sosyal medya fenomenleri takip etmektedir. En az takip edilenler ise sırasıyla din adamları, siyasiler ve öğretmenler olarak tespit edilmiştir.

Tablo 8: Sosyal Medya Kullanım Amaç ve Motivasyonları Ortalamaları

\begin{tabular}{|c|c|c|c|c|c|}
\hline & $\mathrm{N}$ & $\begin{array}{l}\text { Minim } \\
\text { um }\end{array}$ & $\begin{array}{l}\text { Maxim } \\
\text { um }\end{array}$ & Ortalama & SD \\
\hline Ev, okul ve arkadaş çevremdeki dertlerimi unutturuyor & 1026 & 1,00 & 5,00 & 2,6170 & 1,39772 \\
\hline Bir an olsun problemlerimden uzaklaşmak için & 1026 & 1,00 & 5,00 & 2,6891 & 1,40515 \\
\hline Kendimi daha az yalnız hissetmemi sağladığı için & 1026 & 1,00 & 5,00 & 2,3070 & 1,39836 \\
\hline İçimdeki duygu ve heyecanları açığa çıkardığı & 1026 & 1,00 & 5,00 & 2,3070 & 1,28568 \\
\hline Bir gruba aitmiş duygusu hissedebilmek için & 1026 & 1,00 & 5,00 & 1,9220 & 1,18682 \\
\hline Sosyal medya kullanmak bana heyecan veriyor & 1026 & 1,00 & 5,00 & 2,1618 & 1,24827 \\
\hline Beni başka bir dünyaya götürdüğü için & 1026 & 1,00 & 5,00 & 2,2973 & 1,33703 \\
\hline Dinlenmeme yardımcı olduğu için & 1026 & 1,00 & 5,00 & 2,9708 & 1,39166 \\
\hline Başkalarıyla nasıl anlaşabileceğimi gösterdiği için & 1026 & 1,00 & 5,00 & 2,4230 & 1,35013 \\
\hline Arkadaş bulmak, yeni insanlarla tanışmak için & 1026 & 1,00 & 5,00 & 2,2719 & 1,37757 \\
\hline Kafamı boşaltmaya yardımcı olduğu için & 1026 & 1,00 & 5,00 & 3,0302 & 1,42043 \\
\hline Beni sıkan insanlardan kurtulmamı sağladığı için & 1026 & 1,00 & 5,00 & 2,5556 & 1,46415 \\
\hline Konuşacak birisi olmadığında bana arkadaşlık ediyor & 1026 & 1,00 & 5,00 & 2,5828 & 1,47018 \\
\hline Yapacak daha iyi bir işim olmadığında beni oyalıyor & 1026 & 1,00 & 5,00 & 2,7212 & 1,43077 \\
\hline Kendimi özgürce ifade edebilmek için & 1026 & 1,00 & 5,00 & 2,2827 & 1,31261 \\
\hline Başka bir yerde ulaşamadığım bilgilere ulaşmak için & 1026 & 1,00 & 5,00 & 3,3908 & 1,40323 \\
\hline Bir konuda fikir sahibi olmama yardımcı olduğu için & 1026 & 1,00 & 5,00 & 3,2973 & 1,36876 \\
\hline Okuldaki gelişmeler hakkında bilgi sahibi olmak & 1026 & 1,00 & 5,00 & 3,1628 & 1,39330 \\
\hline Güvenilir bir haber kaynağı olduğu için & 1026 & 1,00 & 5,00 & 2,6754 & 1,35392 \\
\hline $\begin{array}{l}\text { Pek çok konuyu diğer medyada yer almadan önce } \\
\text { öğrendiğim için }\end{array}$ & 1026 & 1,00 & 5,00 & 2,9288 & 1,41069 \\
\hline $\begin{array}{l}\text { Yaşadığım şehir/ilçe/köydeki gelişmeler ve etkinlikleri } \\
\text { takip etmek için }\end{array}$ & 1026 & 1,00 & 5,00 & 3,0517 & 1,39765 \\
\hline $\begin{array}{l}\text { Dünyada ve Türkiye'de meydana gelen olayları anında } \\
\text { öğrenmek }\end{array}$ & 1026 & 1,00 & 5,00 & 3,5312 & 1,31983 \\
\hline Bilmediğim şeyleri öğrenebildiğim için & 1026 & 1,00 & 5,00 & 3,5409 & 1,30619 \\
\hline $\begin{array}{l}\text { Boş zamanımı değerlendirmede bana çeşitli alternatifler } \\
\text { sunuyor }\end{array}$ & 1026 & 1,00 & 5,00 & 3,4288 & 1,33227 \\
\hline
\end{tabular}




\begin{tabular}{|c|c|c|c|c|c|}
\hline Sosyal medya kullanmak zevkli & 1026 & 1,00 & 5,00 & 3,4396 & 1,31214 \\
\hline Sosyal medyayı seviyorum & 1026 & 1,00 & 5,00 & 3,4162 & 1,29287 \\
\hline S1kıldığımda vakit geçirmek için & 1026 & 1,00 & 5,00 & 3,6696 & 1,24743 \\
\hline Sosyal medyayı yalnız kullanmayı seviyorum & 1026 & 1,00 & 5,00 & 3,0799 & 1,36201 \\
\hline İlginç şeyler bulmak için & 1026 & 1,00 & 5,00 & 3,2359 & 1,34161 \\
\hline Markaların kampanyalarını takip etmek için & 1026 & 1,00 & 5,00 & 2,4337 & 1,37504 \\
\hline Karlı mali bilgiler elde etmek için & 1026 & 1,00 & 5,00 & 2,0497 & 1,22990 \\
\hline Ürün ve hizmetlerin indirimli olanlarını bulmak için & 1026 & 1,00 & 5,00 & 2,3967 & 1,39110 \\
\hline $\begin{array}{l}\text { Sosyal medyadan alışveriş yapmanın kolaylığını/ } \\
\text { uygunluğunu seviyorum }\end{array}$ & 1026 & 1,00 & 5,00 & 2,6004 & 1,43481 \\
\hline Markaların çekilişlerine katılmak için & 1026 & 1,00 & 5,00 & 2,1062 & 1,28838 \\
\hline Ürün ve hizmetler hakkında yararlı bilgiler edinmek için & 1026 & 1,00 & 5,00 & 2,4357 & 1,36373 \\
\hline Tanınırlığımı arttırmak için & 1026 & 1,00 & 5,00 & 1,8811 & 1,15420 \\
\hline Tanıdığım insanlarla iletişiminde bulunmak için & 1026 & 1,00 & 5,00 & 3,4162 & 1,42702 \\
\hline Ailem ve dostlarımla iletişimde bulunmak için & 1026 & 1,00 & 5,00 & 3,5010 & 1,36810 \\
\hline Diğer insanlarla bilgi paylaşımında bulunabildiğim için & 1026 & 1,00 & 5,00 & 2,8762 & 1,41879 \\
\hline $\begin{array}{l}\text { Başkalarına görüş bildirmek ve tavsiyelerde bulunmak } \\
\text { için }\end{array}$ & 1026 & 1,00 & 5,00 & 2,7593 & 1,40228 \\
\hline $\begin{array}{l}\text { Edindiğim bilgiler hakkında başkalarıyla iletişim } \\
\text { kurabilmek için }\end{array}$ & 1026 & 1,00 & 5,00 & 2,8216 & 1,38436 \\
\hline Başkalarından destek almak için & 1026 & 1,00 & 5,00 & 2,3265 & 1,31172 \\
\hline $\begin{array}{l}\text { Sosyal medyayı her zaman ve her yerde kullanabildiğim } \\
\text { için }\end{array}$ & 1026 & 1,00 & 5,00 & 2,9142 & 1,43219 \\
\hline Yeni insanlar tanımak için & 1026 & 1,00 & 5,00 & 2,2904 & 1,40849 \\
\hline Oyun oynamak için & 1026 & 1,00 & 5,00 & 2,5887 & 1,45046 \\
\hline Sosyal medya eğlence ihtiyacımı karşılıyor & 1026 & 1,00 & 5,00 & 3,1014 & 1,42297 \\
\hline $\begin{array}{l}\text { Çeşitli müzik parçası dinlemek ve MP3 vb. indirmek } \\
\text { için }\end{array}$ & 1026 & 1,00 & 5,00 & 3,5673 & 1,40864 \\
\hline Eğlenceli video izlemek için & 1026 & 1,00 & 5,00 & 3,6579 & 1,29800 \\
\hline Sosyal medyada eğlenceli akımlara katılmak için & 1026 & 1,00 & 5,00 & 2,1784 & 1,33265 \\
\hline Yeni çıkan oyunları takip etmek için & 1026 & 1,00 & 5,00 & 2,2281 & 1,39848 \\
\hline Geçerli Sayı & 1026 & & & & \\
\hline
\end{tabular}

Öğrencilerin sosyal medyayı kullanım amaç ve motivasyonları Tablo 8'de görülmektedir.

Ortaya çıkan sonuçlar incelendiğinde lise çağındaki öğrencilerin sosyal medyayı kullanım amaç ve motivasyonları arasında en yüksek ortalama, 3,66 ile "Sıkıldığımda vakit geçirmek için" ifadesinde ortaya çıkmıştır. Daha sonra ise "Eğlenceli video izlemek için" $(3,65)$, "Çeşitli müzik parçası dinlemek ve MP3 vb. indirmek için" $(3,56)$ maddeleri gelmektedir. Bunu "Bilmediğim şeyleri öğrenebildiğim için” $(3,54)$, “Dünyada ve Türkiye'de meydana gelen olayları anında öğrenmek için” $(3,53)$ ifadeleri takip etmektedir. Katılımcıların sosyal medyayı kullanım amaç ve motivasyonlarının betimleyici istatistik sonuçlarına göre en az ortalamaya sahip ifadeler ise "Tanınırlığımı arttırmak için" ifadesi $(1,88)$ ile "Bir gruba ait olma duygusunu hissedebilmek" $(1,92)$ ifadelerinde ortaya çıkmıştır.

Tablo 9: Cinsiyet İtibariyle Sosyal Medya Kullanım Motivasyonları

\begin{tabular}{|l|llllll}
\hline $\begin{array}{l}\text { Sosyal Medyayı Kullanırım } \\
\text { Çünkü; }\end{array}$ & $\begin{array}{l}\text { Cinsiy } \\
\text { et }\end{array}$ & N & Mean & SD & $\begin{array}{l}\text { Std. Error } \\
\text { Mean }\end{array}$ & $\begin{array}{l}\text { Sig. } \\
\text { tailed) }\end{array}$ \\
\hline $\begin{array}{l}\text { Ürün ve hizmetlerin indirimli } \\
\text { olanlarını bulmak için }\end{array}$ & Erkek & 433 & 2,2009 & 1,34157 &, 06447 &, $\mathbf{0 0 0}$ \\
& Kadın & 592 & 2,5422 & 1,40999 &, 05795 & \\
\hline $\begin{array}{l}\text { Çeşitli müzik parçası dinlemek } \\
\text { ve MP3 vb. download etmek }\end{array}$ & Erkek & 433 & 3,3487 & 1,47537 &, 07090 &, $\mathbf{0 0 0}$ \\
için & Kadın & 592 & 3,7314 & 1,33310 &, 05479 & \\
\hline & & & & & & \\
Yeni çıkan oyunları takip & Kadın & 592 & 1,9595 & 1,24293 &, 05108 &, 000 \\
etmek için & & & & & & \\
\hline
\end{tabular}

Araştırmanın sosyal medya kullanım gerekçelerini ortaya çıkarmak için katılımcılara yöneltilen soru grubunun maddeleri ile katılımcıların cinsiyetleri arasında bir farklılaşma olup 
olmadığını ortaya koymak için yapılan t-testi sonuçlarına göre, üç maddede kadınlar ile erkekler arasında anlamlı bir ilişki ortaya çıkmıştır $(\mathrm{P}<0,00)$. Buna göre "Ürün ve hizmetlerin indirimli olanlarını bulmak için", "Çeşitli müzik parçası dinlemek ve MP3 vb. indirmek k için" ve "Yeni çıkan oyunları takip etmek için" maddelerinde katılımcıların cinsiyetleri arasında anlamlı bir ilişki olduğu görülmektedir. Ortaya çıkan sonuçlar Tablo 9' da sunulmuştur. Tablo 9' da görüldüğü üzere sosyal medyayı ürün ve hizmetlerin indirim oranlarından faydalanmak için kullananlar karşılaştıııldığında kadınların $(2,5422)$ erkeklere $(2,2009)$ göre ortalamasının daha yüksek olduğu görülmektedir. Yine aynı şekilde kadınların $(3,7314)$, erkeklere $(3,3487)$ oranla ortalamasının yüksek olduğu bir diğer madde ise "Çeşitli müzik parçası dinlemek ve MP3 vb. indirmek için" ifadesidir. Lise çağındaki gençlerin sosyal medya kullanım amacı olarak yeni çıkan oyunları takip etme durumlarında ise erkeklerin $(2,5958)$ kadınlara $(1,9595)$ oranla daha fazla ortalamaya sahip olduğu görülmektedir.

Tablo 10: Sosyal Medya Kullanım Amaç ve Motivasyonları Öz Değeri, Açıklanan Varyansları ve Güvenilirlik Katsayıları

\begin{tabular}{|c|c|c|c|}
\hline Faktörler & Öz değer (Eigenvalue) & Açılkanan Varyans & $\begin{array}{l}\text { Cronbach's Alpha } \\
(\alpha)\end{array}$ \\
\hline Sosyal Kaçıs Faktörü & 17,450 & $\% 14,444$ & 0,91 \\
\hline $\begin{array}{l}\text { Boş Zaman Değerlendirme } \\
\text { Faktörü }\end{array}$ & 3,700 & $\% 12,189$ & 0,89 \\
\hline Bilgilenme Faktörü & 2,934 & $\% 10,263$ & 0,87 \\
\hline Ekonomik Fayda Faktörü & 2,176 & $\% 9,167$ & 0,88 \\
\hline Sosyal Etkileşim Faktörü & 1,683 & $\% 7,432$ & 0,88 \\
\hline Eğlence Faktörü & 1,334 & $\% 5,059$ & 0,82 \\
\hline TOPLAM & & $\% 58,554$ & 0,96 \\
\hline $\begin{array}{l}\text { KMO } \\
\text { (Keiser-Meyer-Olkin } \\
\text { Measure of Sampling } \\
\text { Adequacy) }\end{array}$ & \multicolumn{3}{|l|}{0,960} \\
\hline Bartlet's Test of Sphericty & \multicolumn{3}{|c|}{$\mathrm{x}^{2}=31382,744 \mathrm{df}=1225 \mathrm{p}=, 000$} \\
\hline
\end{tabular}

Araştırma kapsamında lise öğrencilerinin sosyal medya kullanım alışkanlıkları ve motivasyonlarının ortaya çıkmasında etkili olan faktörleri ortaya koymak için katılımcıların sorulara verdikleri 49 maddeye faktör analizi yapılmış; öz değer (eigenvalue) ve yamaç eğrisi grafiğinin (screeplot) incelenmesi sonucunda 6 adet faktör grubunun ele alınabileceği görülmüştür. Diğer taraftan araştırma kapsamında deneklere yöneltilen bütün maddeler ile faktör analizi yapılan maddeler kendi içerisinde güvenilirlik analizi yapılmıştır.

Araştırmamızın faktör analizi sonucuna göre Bartlett testi sonucu $\mathrm{p}=0,000<0,05$ olduğundan dolayı değişkenler arasında anlamlı bir ilişkiden söz edilebilir. Diğer taraftan $\mathrm{KMO}=0,960$ olarak 
hesaplanmıştır. $\mathrm{KMO}=0,960>0,60$ olduğundan dolayı örneklem büyüklügünün faktör analizi için uygun olduğu söylenebilir. Araştırmamız kapsamında faktör analizi yapılan madde sayısı 49'dur. Analiz neticesinde ise altı adet faktör tanımlanmıştır. Bunlar sosyal kaçış, bilgilenme, boş zaman, ekonomik fayda, sosyal etkileşim ve eğlence faktörleridir. Faktör analizi yapılan maddelerin güvenilirlik analizleri birinci grup; (Cronbach's $\alpha$ ) 0,918, ikinci grup 0,891, üçüncü grup 0,874, dördüncü grup 0,885 , beşinci grup 0,883 ve altıncı grup ise 0,827 olarak ortaya çıkmıştır. Tüm faktör maddelerinin güvenilirlik katsayısı ise 0,961 olarak tespit edilmiştir. Bu veriler bize güvenilir bir ölçüm yapıldığını göstermektedir (Cronbach's $\alpha>0,70)$. Faktör analizi neticesinde açılanan toplam varyans ise $\% 58,554$ 'tür.

Yapılan faktör analizi sonuçlarına göre, birinci grupta 15 maddeyi bir arada toplayan sosyal kaçış faktörü ilk sırada gelmektedir. $\mathrm{Bu}$ faktörün maddeleri incelendiğinde lise öğrencilerinin; "daha az yalnız hissetmek, problemlerden uzaklaşmak, bir gruba aitmiş gibi hissetmek, beni sıkan insanlardan uzaklaşmak" gibi nedenlerle sosyal medyaya yöneldikleri görülmektedir. Sosyal kaçış faktör grubu, toplam varyansın \%14,444'ünü açıklamıştır. Sosyal kaçış faktörünün öz değeri (Eigenvalue) 17,450'dir.

Faktör analizi neticesinde ortaya çıkan ikinci faktör grubu, boş zaman değerlendirmedir. $\mathrm{Bu}$ faktörü oluşturan maddeler incelendiğinde "Sosyal medya kullanmak zevkli”, "Sosyal medyayı seviyorum", "Sıkıldığımda vakit geçirmek için" gibi maddeler öne çıkmaktadır. Boş zaman değerlendirme faktörü toplam varyansın \%12,189'unu açıklarken faktörün öz değeri (Eigenvalue) ise 3,700 olarak yüksek seviyede çıkmıştır.

Üçüncü faktör grubu "bilgilenme faktörü” olarak adlandırılmıştır. Bu gruba ait maddeler incelendiğinde "Başka bir yerde ulaşamadığım bilgilere ulaşmak için", "Bilmediğim şeyleri öğrenebildiğim için”, "Okuldaki gelişmeler hakkında bilgi sahibi olmak için" maddeleri dikkat çekmektedir. Bilgilenme faktörü toplam varyansın \%10,263'ünü oluştururken, faktörün öz değeri 2,934 seviyesinde ortaya çıkmıştır.

Toplam varyansın \%9,167'sini oluşturan ekonomik fayda faktörü, analizimizin dördüncü faktör grubunu oluşturmaktadır. Sonuçlar incelendiğinde "Markaların kampanyalarını takip etmek için", "Ürün ve hizmetlerin indirimli olanlarını bulmak için" ve "Markaların çekilişlerine katılmak için” gibi maddeler göze çarpmaktadır. Ekonomik fayda faktörünün öz değeri ise 2,176 olarak ortaya çıkmıştır. Bu oran tatmin edici bir orandır.

Analiz sonucunda ortaya çıkan beşinci faktör "sosyal etkileşim faktörü" olarak adlandırılmıştır. Ortaya çıkan sonuçlara göre "Ailem ve dostlarımla iletişimde bulunmak için”, "Edindiğim bilgiler hakkında başkalarıyla iletişim kurabilmek için", "Diğer insanlarla bilgi paylaşımında bulunabildiğim için” gibi maddelerin faktör ağırlıkları ön plana çıkmaktadır. Sosyal etkileşim faktörü, toplam varyansın \%7,43'ünü oluştururken öz değer 1,68 olarak ortaya çıkmıştır. 
Altıncı ve son faktör ise "eğlence faktörü" olarak adlandırılmıştır. Eğlence faktörü toplam varyansın \%5,059'unu açıklamaktadır. "Yeni çıkan oyunları takip etmek için” ve "Oyun oynamak için" maddelerinin öne çıktığı eğlence faktörünün öz değeri ise 1,3134 olarak hesaplanmıştır. Bu oran kabul edilebilir sınırlar dâhilindedir.

Tablo 11: Korelasyon Analizi Sonuçları

\begin{tabular}{|l|l|l|l|l|l|l|}
\hline $\begin{array}{l}\text { Korelasyon } \\
\text { Analizi }\end{array}$ & $\begin{array}{l}\text { Sosyal } \\
\text { Kaçış }\end{array}$ & $\begin{array}{l}\text { Boş Zaman } \\
\text { Değerlendirme }\end{array}$ & Bilgilenme & $\begin{array}{l}\text { Ekonomik } \\
\text { Fayda }\end{array}$ & $\begin{array}{l}\text { Sosyal } \\
\text { Etkileşim }\end{array}$ & Eğlence \\
\hline Sosyal Kaçış & 1 &, $620^{* *}$ &, $456^{* *}$ &, $495^{* *}$ &, $625^{* *}$ &, $634^{* *}$ \\
\hline $\begin{array}{l}\text { Boş Zaman } \\
\text { Değerlendirme }\end{array}$ &, $620^{* *}$ & 1 &, $561^{* *}$ &, $541^{* *}$ &, $618^{* *}$ &, $669^{* *}$ \\
\hline Bilgilenme &, $456^{* *}$ &, $561^{* *}$ & 1 &, $517^{* *}$ &, $637^{* *}$ &, $461^{* *}$ \\
\hline $\begin{array}{l}\text { Ekonomik } \\
\text { Fayda }\end{array}$ &, $495^{* *}$ &, $541^{* *}$ &, $517^{* *}$ & 1 &, $568^{* *}$ &, $479^{* *}$ \\
\hline $\begin{array}{l}\text { Sosyal } \\
\text { Etkileşim }\end{array}$ &, $625^{* *}$ &, $618^{* *}$ &, $637^{* *}$ &, $568^{* *}$ & 1 &, $620^{* *}$ \\
\hline Eğlence &, $634^{* *}$ &, $669^{* *}$ &, $461^{* *}$ &, $479^{* *}$ &, $620^{* *}$ & 1 \\
\hline
\end{tabular}

Correlation is significant at the 0.01 level (2-tailed).

Araştırma kapsamında ortaya çıkan faktörlerin arasındaki ilişkinin gücünü ve yönünü

tespit etmek amacıyla yapılan korelasyon analizi neticesinde ortaya çıkan sonuçlar Tablo 11'de görülmektedir. Tablo 11'e göre faktörler arasında orta düzeyde pozitif yönlü ilişkiler saptanmıştır. Ortaya çıkan sonuçlar incelendiğinde en güçlü ilişki boş zaman ve eğlence faktörleri arasında çıkmıştır $(\mathrm{r}=, 669 ; \mathrm{p}<, 01)$. Diğer bir ifadeyle boş zamanlarını sosyal medyada geçiren lise öğrencileri aynı zamanda eğlence faktörüne de önem vermektedir. Yine bilgi edinme faktörü ile sosyal etkileşim faktörü arasında da orta düzeyde pozitif yönlü bir ilişki saptanmıştır $(r=, 637$; $\mathrm{p}<, 01)$. Diğer taraftan orta düzeyde pozitif yönlü en düşük değerlere sahip olan faktörler ise sosyal kaçış ve bilgilenme faktörleri olarak ortaya çıkmıştır $(r=, 456 ; p<, 01)$.

Tablo 12: Cinsiyete İtibariyle Sosyal Medyada Geçirilen Süre

\begin{tabular}{lllll}
\hline & & Cinsiyet & Kadın & Toplam \\
\cline { 2 - 5 } & & Erkek & 205 & 412 \\
& $1-2$ saat & 207 & $49,8 \%$ & $100,0 \%$ \\
& & $50,2 \%$ & $20,0 \%$ & $40,2 \%$ \\
\cline { 2 - 5 } & & $20,2 \%$ & 232 & 382 \\
& & 150 & $60,7 \%$ & $100,0 \%$ \\
S-4 saat & $39,3 \%$ & $22,6 \%$ & $37,3 \%$ \\
Medyal & & $14,6 \%$ & 96 & 152 \\
Ortalama & $5-6$ saat & 56 & $63,2 \%$ & $100,0 \%$ \\
Geçirilen & & $36,8 \%$ & $9,4 \%$ & $14,8 \%$ \\
Süre & & $5,5 \%$ & 31 & 41 \\
& & 10 & $75,6 \%$ & $100,0 \%$ \\
& & $24,4 \%$ & $3,0 \%$ & $4,0 \%$ \\
\hline & & $1,0 \%$ & 28 & 38 \\
\hline
\end{tabular}




\begin{tabular}{|c|c|c|c|c|}
\hline & \multirow{2}{*}{$\begin{array}{ll}8 & \text { saatten } \\
\text { fazla } & \end{array}$} & $26,3 \%$ & $73,7 \%$ & $100,0 \%$ \\
\hline & & $1,0 \%$ & $2,7 \%$ & $3,7 \%$ \\
\hline \multirow[t]{3}{*}{ Toplam } & & 433 & 592 & 1025 \\
\hline & & $42,2 \%$ & $57,8 \%$ & $100,0 \%$ \\
\hline & & $42,2 \%$ & $57,8 \%$ & $100,0 \%$ \\
\hline
\end{tabular}

$(x 2=23,317 d f=4 p=0,000)$

Tablo 12 lise öğrencilerinin sosyal medya kullanım sıklıklarının cinsiyet itibarıyla farklı1ık gösterip göstermediğine dair ki-kare testi sonuçlarını göstermektedir. Ki-kare testi sonuçları sosyal medya kullanım sıklıkları ile katılımcıların cinsiyetleri arasında anlamlı bir ilişki olduğunu göstermektedir $(\mathrm{p}=0,000)$. Tablo 12 incelendiğinde ortaya çıkan veriler kadınların erkeklere göre sosyal medyayı daha fazla kullandıklarını göstermektedir.

\section{Sonuç}

Son yıllarda toplumlarda internet teknolojilerinin yayılmasıyla paralel olarak sosyal medya kullanımı da artmıştır. Günümüzde artık genç yaşlardan itibaren kullanılmaya başlanan internet teknolojileri birçok avantajın yanında farklı sorunları da beraberinde getirmektedir. Öte yandan bireylerin sosyal medyaya olan bağımlılık dereceleri ve sosyal medya karşısında geçirilen süre zamanlarının önemli bir kısmını almaktadır. Bu durum özellikle gençlerde birtakım sorunları da beraberinde getirmektedir. Sosyal medyanın bu denli yaygın kullanımı ve zamanla bir bağımlılığa dönüşmesi akıllara bireylerin sosyal medya kullanım amaçlarının ve motivasyonlarının neler olduğu sorusunu beraberinde getirmektedir. Bununla beraber sosyal medyayı etkin bir biçimde kullanan gençler, bu sorunun önemli muhataplarındandır. Buradan hareketle bu çalışma lise çağındaki gençler üzerine odaklanılarak lise öğrencilerinin sosyal medya kullanım amaç ve motivasyonlarını ortaya çıkarmak amacıyla yapılmıştır.

Çalışmada lise öğrencilerinin sosyal medya kullanım amaç ve motivasyonları incelenmiş ve altı adet faktör öne çıkmıştır. Bu faktörler sosyal kaçış faktörü, bilgilenme faktörü, boş zaman faktörü, ekonomik fayda faktörü, sosyal etkileşim faktörü ve eğlence faktörüdür. Bu faktörlerden sosyal kaçış faktörü toplam varyansın \%14,444'ünü açıklayarak öne çıkmaktadır. Korelasyon analizine göre dikkat çeken sonuçlar; boş zaman ve eğlence faktörleri arasında ve bilgi edinme faktörü ile sosyal etkileşim faktörleri arasındadır. Sosyal kaçış ve bilgilenme faktörleri arasındaki anlamlı ilişki ise en düşük değere sahip sonuç olarak dikkat çekmektedir.

Araştırma kapsamında belirlenen altı adet faktörün maddelerinin betimsel olarak analizi yapıldığında ortalaması en yüksek çıkan maddeler; "Sıkıldığımda vakit geçirmek için", "Eğlenceli video izlemek için" ve "Çeşitli müzik parçası dinlemek ve MP3 vb. indirmek için" maddeleri dikkat çekmektedir. En düşük ortalama ise "Tanınırlı̆̆ımı arttırmak için" ve "Bir gruba ait olma duygusunu hissedebilmek için" maddelerinde ortaya çıkmıştır.

Araştırma sonuçlarında öne çıkan bir başka veri ise sosyal medya kullanım sıklıkları ile ilgilidir. Ortaya çıkan sonuçlar, Instagram ve Facebook gibi fotoğraf ve video paylaşım sitelerini 
lise çağındaki erkeklerin kadınlardan daha fazla kullandığını göstermektedir. Öte yandan video paylaşım ve izleme sitesi olan YouTube ile gönderi paylaşım sitesi olan Twitter ve mesajlaşma/arama uygulaması olan Whatsapp'ı ise lise çağındaki kadınların lise çağındaki erkeklerden daha fazla kullandığı görülmektedir. Cinsiyet fark etmeksizin sosyal medya araç ve uygulamaları arasında en fazla tercih edilen platform Whatsapp; en az tercih edilen ise Facebook olarak ortaya çıkmıştır.

Lise çağındaki gençlerin sosyal medyada kimleri takip ettiklerine baktığımızda ise; en fazla arkadaşlarını, ailesini, akrabalarını ve sosyal medya fenomenlerini takip ettikleri görülmektedir. Diğer taraftan siyasileri ve öğretmenlerini takip etme sıklıkları daha düşük düzeyde kalmıştır.

Sosyal medya konusu farklı perspektiflerden ele alınan ve üzerinde araştırmalar yapılan önemli bir çalışma alanıdır. Bu çalışma ile ortaya çıkan sonuçların ileride yapılacak olan; sosyal medya bağımlılığı, sosyal medya kullanımı ve motivasyonu, sosyal medya okuryazarlığı gibi konularda araştırmacılara bir yol gösterici olacağı düşünülmektedir. Ayrıca çalışma, gençlerin sosyal medya kullanım sıklıklarının ortaya çıkarılması hususunda gerek özel kurumlarının gerekse de kamu kurumlarının, lise çağındaki gençlere yönelik sosyal medya üzerinden yapacağ halkla ilişkiler, reklam ve diğer uygulamalar için önemli veriler sunmaktadır.

Sonuç olarak sosyal medya kullanımı günümüzde kullanımı sürekli artan ve insanları birçok açıdan etkileyen bir yapı olarak karşımıza çıkmaktadır. Gençler bağlamında bakıldığında sosyal medya gençlerin apolitikleşmesi, dünya görüşlerinin şekillendirilmesi gibi konularda gençler üzerinde etkili bir yapı olarak ele alınabilir. Şüphesiz sosyal medyanın gençler üzerindeki bu etkileri toplumsal, kültürel ve ekonomik yapıyla da yakından ilişkilidir. Diğer taraftan sosyal medyayı etkin bir biçimde kullanan lise çağındaki gençler de zamanlarının önemli bir kısmını bu platformlarda harcamaktadırlar. Bu çalışma ile lise çağındaki gençlerin sosyal medya kullanım amaçlarının ve motivasyonlarının ortaya çıkarılması bakımından literatüre ampirik verilerle katkı sağlamak amaçlanmıştır. Konu ile ilgili daha geniş örneklem üzerinde yapılacak olan çalışmalar konunun daha iyi anlaşılmasını sağlayacaktır.

\section{Kaynaklar}

Abidin, C. (2018). Internet Celebrity: Understanding Fame Online. Bingley UK: Emerald Publishing Limited.

Acun, İ., Yücel, C., Belenkuyu, C., \& Keleş, S. (2017). Üniversite Öğrencilerinin Sosyal Medya Kullanım Amaçlarının İncelenmesi. Kuram ve Uygulamada Ĕgitim Yönetimi, 23(4), 559602.

Açıkgöz, F. Y., \& Yalman, A. (2018). Oyunların Çocukların Kişilik ve Davranışları Üzerinde Etkisi: Gta 5 Oyunu Örneği. Akdeniz İletişim(29. Özel Sayısı), Akdeniz İletişim, 0(0), 163-180. 
Akar, F. (2015). Purposes, Causes and Consequences of Excessive Internet Use among Turkish Adolescents. Eurasian Journal of Educational Research, 15(60), 35-56.

Akgün, V. Ö., \& Ergün, G. S. (2017). Yeni Müşteri Kavramı ve Modern Pazarlama Sürecinde Sosyal Medya Pazarlaması. Turkish Studies, 12(32), 17-32.

Aksoy, H., \& Gür, A. (2018). Üniversite Öğrencilerinin Sosyal Medya Reklamlarına İlişkin Algılarının Satın Alma Niyeti Üzerindeki Etkisi. Cumhuriyet Üniversitesi İktisadi ve İdari Bilimler Dergisi, 19(1), 129-148.

Aksoy, M. (2015). Seçim Kampanyalarında Sosyal Medya Kullanımı: Facebook ve 2014 Cumhurbaşkanlığg Seçimleri. Elektronik Sosyal Bilimler Dergisi (Elektronik), 14(55), 98114.

Aksoy, R. (2006). Bir Pazarlama Değeri Olarak Güven ve Tüketicilerin Elektronik Pazarlara Yönelik Güven Tutumları. Zonguldak Karaelmas Üniversitesi Sosyal Bilimler Dergisi, 2(4), 79-90.

Alaca, F., \& Tatlı, H. (2018). Akademisyenlerin Mobil İnternet Tercihini Etkileyen Davranışsal ve Demografik Faktörler. Ajıt-E: Bilişim Teknolojileri Online Dergisi, 9(30), 121-136.

Alakurt, T. (2016). Öğretmen Adaylarının Sosyal Medya Kullanım Motivasyonları İle Öğrenme Stillerinin İncelenmesi. Ankara Üniversitesi Eğitim Bilimleri Fakültesi Dergisi, 49(1), 43-63.

Alan, A. K., Kabaday1, E. T., \& Uzunburun, T. (2018). Sosyal Medya Pazarlama Faaliyetlerinin Müşteri Varlığı ve Müşteri Bağlılığına Etkisi. Uluslararası Yönetim İktisat ve İsletme Dergisi, 14(2), 535-556.

Albayrak, E. (2019). Sosyal Ağlar Ve Modern İnsanın Yalnızlaşması: Cocacola Reklam Örneği. Elektronik Sosyal Bilimler Dergisi, 18(70), 929-942.

Altıncık, H., \& Yaşar, İ. H. (2017). Yardım Kuruluşları Kızılay ve Kızılhaç'ın Sosyal Medya Uygulamalarında İletişimin Yönüne ve Konu Dağılımlarına Yönelik Bir Analiz. Dicle Üniversitesi İktisadi ve İdari Bilimler Fakültesi Dergisi, 7(13), 101-113.

Alyakut, Ö. (2017). Kahve Markalarının Bütünleşik Pazarlama İletişimi Bağlamında Sosyal Medya Kullanımları. Afyon Kocatepe Üniversitesi Sosyal Bilimler Dergisi, 19(2), 209234.

Arklan, Ü. (2016). Sosyal Medyanın Siyasal Amaçlı Kullanımı: A ̆g Kuşağının Kullanım Alışkanlıkları Üzerine Bir Araştırma. Gümüşhane Üniversitesi Illetişim Fakültesi Elektronik Dergisi, 4(2), 618-657.

Asare-Donkoh, F. (2018). Impact of Social Media on Ghanaian High School Students. Library Philosophy \& Practice, 1-33.

Atar, G., \& İspir, N. (2019). Geleneksel ve Sosyal Medyada Reklama Yönelik Tutum ve Reklam Değeri Arasındaki İlişkinin Karşılaştırılması. Akdeniz İletişim(32), 305-322.

Aycı, A. (2018). Kobi'lerin Pazarlama İletişiminde Sosyal Medyanın Rolü: Genç Girişimcilere Yönelik Bir Araştırma. Akdeniz İletişim(29. Özel Sayı), 36-56.

Aydın, İ. (2016). Üniversite Öğrencilerinin Sosyal Medya Kullanımları Üzerine Bir Araştırma: Anadolu Üniversitesi Örneği. Selçuk Üniversitesi Sosyal Bilimler Enstitüsü Dergisi(35), 373-386.

Aytan, C., \& Eser, E. (2014). Markaların Sosyal Medya Kullanımının Tüketici Davranışı Üzerindeki Etkiler. The Turkish Online Journal of Design, Art and Communication, 4(4), $1-15$. 
Balay, R., Kaya, A., \& Çevik, M. (2014). Öğretmenlerin İnternete Yönelik Tutumlar1 ve Eğitsel İnternet Kullanım Öz Yeterlik İnanç Düzeyleri. Karadeniz Uluslararası Bilimsel Dergi(23), 16-31.

Balcı, Ş. (2009). Üniversite Öğrencileri Arasında İnternet Bağımlılığı ve İnternet Bağımlılarının Profili. Selçuk İletişim, 6(1), 5-22.

Balc1, Ş., \& Ayhan, B. (2007). Üniversite Öğrencilerinin İnternet Kullanım ve Doyumları Üzerine Bir Saha Araştırması. Selçuk Illetişim, 5(1), 174-197.

Barutçu, S., \& Tomaş, M. (2013). Sürdürülebilir Sosyal Medya Pazarlaması ve Sosyal Medya Pazarlaması Etkinliğinin Ölçümü. İnternet Uygulamalarl ve Yönetimi, 4(1), 5-24.

Bayrakdaroğlu, A. (2012). Bireylerin İnternet Bankacılığı Kullanımını Etkileyen Faktörlerin Belirlenmesi Üzerine Bir Alan Araştırması. İşletme ve Ekonomi Araştırmaları Dergisi, 3(4), 57-75.

Bennet, A. (2014). Social Media: Global Perspectives, Applications And Benefits and Dangers. New York: Nova Science Publishers, Inc.

Bilgin, Y. (2018). The Effect of Social Media Marketıng Actıvities on Brand Awareness, Brand Image and Brand Loyalty. Business and Management Studies. An International Journal, $6(1), 128-147$.

Biszko, J. P. (2019). Consolidating and Automating Social Media Impacts to Risk. Air \& Space Power Journal,, 33(4), 58-62.

Can, L. (2017). Sosyal Medyada Kulaktan Kulağa İletişime Yönelik İhtiyacın Marka Bağlılığına Etkisi. İnsan ve Toplum Bilimleri Araştırmaları Dergisi, 6(1), 140-158.

Ceyhan, A. (2011). Ergenlerin Problemli İnternet Kullanım Düzeylerinin Yordayıcıları. Çocuk ve Gençlik Ruh Să̆llğı Dergisi, 18-2, 85-94.

Çağlar, N., \& Köklü, P. (2017). Yeni Medyanın Siyasal İletişim Aracı Olarak Kullanımı: Siyasal Partilerin Resmi Web Sitelerine Yönelik Bir Araştırma. Gümüşhane Üniversitesi İletişim Fakültesi Elektronik Dergisi, 5(1), 148-173.

Çakırkaya, M., \& Koçyiğit, M. (2019). Sosyal Medya İletişimi ve Tüketici Temelli Marka Değeri Arasındaki İlişkinin İncelenmesi: Bir Gsm Markası Üzerine Tüketici Araştırması. İşletme Araştırmaları Dergisi, 11(3), 2027-2039.

Çelik, M. (2016). The Impact of Social Media on Luxury Consumptıon. The Turkish Online Journal Of Design, Art And Communication, 6(4), 437-445.

Çelik, S. (2014). Sosyal Medyanın Pazarlama İletişimine Etkileri. Erciyes İletişim Dergisi, 3(3), 28-42.

Çemrek, F., Baykuş, H., \& Özaydın, Ö. (2014). Sosyal Medya Kullanım ve Davranışlarının Kullanımlar ve Doyumlar Yaklaşımı Bağlamında İncelenmesi: Eskişehir Osmangazi Üniversitesi Örneği. Alphanumeric Journal, 2(2), 61-76.

Çetin , M. H. (2011). Sosyal Medya Bağımlılı̆̆ Bir Alan Araştırması. Illetişim Kuram ve Araştırma Dergisi, 0(32), 151-175.

Çifci, S., \& Sözen, D. (2017). Tüketicilerin Sosyal Medya Pazarlama Aktivitelerine Katılımlarının Etkileyicileri ve Sonuçları. Ege Akademik Bakış, 17(4), 505-515.

Dağtaş, E., \& Yıldırım, O. (2015). İnternet ve Sosyal Ağlar Dolayımlı Gündelik Yaşam Pratikleri: Anadolu Üniversitesi Öğrencileri Üzerine Mikro Alan Araştırması. Folklor/Edebiyat, 21(83), 149-180. 
Demir, İ., Özköklü, D., \& Turğut, B. (2015). Ergenlerin Problemli İnternet Kullanımının Yordanmasında Denetim Odağ ve Yaşam Doyumunun Rolü. Mersin Üniversitesi Eğitim Fakültesi Dergisi, 11(3), 720-731.

Doğan, V., \& Özkara, B. (2013). İnternet Ortamında Markaya Güvenin Online Markaların İmajı Üzerindeki Rolü. İnternet Uygulamalart ve Yönetimi, 4(2), 5-20.

Döş, B., \& Özşahin, C. (2019). Öğretmenlerin Sosyal Medya Bağımlılığı, Öğretmenlik ÖzYeterlilikleri ve Motivasyonları Arasındaki İlişkinin İncelenmesi. Elektronik Sosyal Bilimler Dergisi, 18(71), 1397-1408.

Duğan, Ö. (2018). Sosyal Medya Kaynaklı Krizlerin ‘İmaj Restorasyon Teorisi’ Açısından Örnek Olaylar Üzerinden İncelenmesi. Akdeniz İletişim(29), 293-313.

Dural, A., \& Dural, Ş. (2015). Reklam İletileri Çerçevesinde Çocuk Güvenliği- Çocuk Hakları ve Medya Etiği. Elektronik Sosyal Bilimler Dergisi, 14(53), 2-13.

Ekşi, F., \& Ümmet, D. (2013). Bir Kişilerarası İletişim Problemi Olarak İnternet Bağımlılı̆̆ı ve Siber Zorbalık. Psikolojik Danışma Açısından Değerlendirilmesi, 11(25), 91-115.

Emerick, E., Caldarella, P., \& Black, S. J. (2019). Benefits and Distractions of Social Media As Tools For Undergraduate Student Learning. College Student Journal, 53(3), 265-276.

Emirza, E., İştahlı, S., \& İ. Y. (2012). Sosyal Medyanın Çok Katlı Pazarlamada Kullanımı ve İş Tatmini Üzerindeki Etkileri. Yönetim ve Ekonomi Araştırmaları Dergisi(18), 20-32.

Erişke, T., Kabadayı, E., \& A. A. (2018). İletişimin Yeni Yüzü: Dijital Pazarlama ve Sosyal Medya Pazarlaması. Elektronik Sosyal Bilimler Dergisi, 17(66), 493-504.

Erkan, G., \& Ayhan, A. (2018). Siyasal İletişimde Dezenformasyon ve Sosyal Medya: Bir Doğrulama Platformu Olarak Teyit.Org. Akdeniz İletişim(29. Özel Sayıs1), 202-223.

Erkek, S. (2016). Kamu Kurumlarında Sosyal Medya Kullanımı: Sağlık Bakanlığı Örneği. Selçuk Üniversitesi Sosyal Bilimler Enstitüsü Dergisi(35), 141-150.

Erol, F. (2017). Dijital Dünyanın Sosyal Uçurumları Kapamadaki Rolü: Sosyal Medya ve Sosyal Pazarlama İlişkisi Üzerine Bir İnceleme. Gümüşhane Üniversitesi Sosyal Bilimler Enstitüsü Elektronik Dergisi, 8(21), 33-48.

Eşitti, Ş. (2015). Bilgi Çağında Problemli İnternet Kullanımı ve Enformasyon Obezitesi: Problemli İnternet Kullanımı Ölçeğinin Üniversite Öğrencilerine Uygulanması. İstanbul Üniversitesi İletişim Fakültesi Dergisi(49), 75-97.

Etter, M., Ravasi, D., \& Colleoni, E. (2019). Social Media and The Formation of Organizational Reputation. Academy Of Management Review, 44(1), 28-52.

Evren, F. (2017). Dijital Oyunlarda İdeolojinin Sunumu: Gta IV Örneği. The Turkish Online Journal Of Design, Art And Communication, 7(2), 264-284.

Gao, H., Tate, M., Zhang, H., Chen, S., \& Liang, B. (2018). Social Media Ties Strategy in International Branding: An Application of Resource-Based Theory. Journal of International Marketing, 26(3), 45-69.

Girgin, H. (2016). Sosyal Medyada Yayımlanan Reklamların Vergisel Açıdan Değerlendirilmesi. Vergi Raporu(200), 71-78.

Givens-Carroll, D., Narro, A. J., \& Slade, A. (2015). Television, Social Media, and Fan Culture. Lanham: Lexington Books.

Gökçearslan, Ş., \& Seferoğlu, S. (2016). Ortaokul Öğrencilerinin İnternet Kullanım Biçimleri: Riskli Davranışlar ve Fırsatlar. Kastamonu Üniversitesi Kastamonu Eğitim Dergisi, 24(1), 383-404. 
Göksu, İ., Alan, A., \& Karakuş, T. (2016). Changes in Sociocultural Representatıons in Popular Digital Games. The Turkish Online Journal of Design, Art And Communication, 6(1), 2135.

Göksu, O. (2018). 10 Ağustos 2014 Cumhurbaşkanlığ1 Seçimi: Siyasal Kampanyaların Yeni Medya Boyutunun Analizi. Turkish Studies, 13(7), 123-140.

Göldağ, B. (2017). Ortaöğretim Kurumlarında Öğrenim Gören Öğrencilerin İnternet Bağımlılık Düzeyleri İle Sürekli Kaygı Düzeyleri Arasındaki İlişkinin İncelenmesi. Turkish Studies, 12(11), 71-94.

Grewal, L., Stephen, A. T., \& Coleman, N. V. (2019). When Posting About Products on Social Media Backfires: The Negative Effects of Consumer Identity Signaling on Product Interest. Journal of Marketing Research, 56(2), 197-210.

Gümüş, N., \& Kütahyalı, D. (2017). Kobi'lerin Pazarlama Çalışmalarında Sosyal Medya Kullanma ve Kullanmama Nedenlerinin Belirlenmesi: Kastamonu İlinde Bir Araştırma. Uluslararası Yönetim İktisat ve İşletme Dergisi, 13(4), 891-910.

Günlü, A., \& Ceyhan, A. (2017). Ergenlerde İnternet ve Problemli İnternet Kullanım Davranışının İncelenmesi. Addicta:: The Turkish Journal On Addictions, 4(1), 75-95.

Güven, G. Y. (2010). Ülkeler Arası Katalizör Olarak Sosyal Medya. Tübitak Projesi, Proje No: $112 \mathrm{k} 362$.

Güzel, E. (2016). Dijital Kültür ve Çevrimiçi Sosyal Ağlarda Rekabetin Aktörü "Dijital Habitus". Gümüşhane Üniversitesi İletişim Fakültesi Elektronik Dergisi, 4(1), 82-103.

Işık, M. (2005). Kitle İletişim Teorilerine Giriş. Konya: Eğitim Yayınevi.

Johnston, W. J., K. S., Le, A. N., \& Ming-Sung Cheng, J. (2018). Behavioral Implications of International Social Media Advertising: An Investigation of Intervening and Contingency Factors. Journal of International Marketing, 26(2), 43-61.

Kalburan, Ç., Aydın, O., \& Haşıloğlu, S. (2018). İnternet'ten Alışveriş Faktörleri Modelinin Oluşturulması ve Bilişsel Haritalama Tabanlı Karar Verme. Tüketici Ve Tüketim Araştırmaları Dergisi, 10(1), 79-100.

Kanuri, V. K., Chen, Y., \& Sridhar, S. (2018). Scheduling Content on Social Media: Theory, Evidence, and Application. Journal of Marketing, 82(6), 89-108.

Karahanna, E., Xu, S. X., Xu, Y., \& Zhang, N. (2018). The Needs-Affordances-Features Perspective For The Use of Social Media. Mis Quarterly, 42(3), 737-756.

Kartal, A., \& Algül, A. (2019). Vakıf ve Devlet Üniversitelerinin Kurumsal İmaj Bağlamında Twitter Paylaşımlarının İçerik Analizi. The Turkish Online Journal of Design, Art and Communication, 9(1), 57-70.

Kartal, O., Yazgan, A., \& Kıncal, R. (2017). Bilişim Çağında Sosyal Sermayenin Yeni Belirleyicileri: Dijital Uçurum ve Sosyal Medya Okuryazarlığı. Ahi Evran Üniversitesi Kırşehir Eğitim Fakültesi Dergisi, 18(2), 353-373.

Kayapınar, Ö., Kayapınar, P., \& Tan, Ö. (2017). Sosyal Medya Reklamlarına Yönelik Tüketici Algıları İle E-Sadakat Arasındaki İlişkide Markaya Yönelik Tutumun Rolü. İşletme Araştırmaları Dergisi, 9(4), 472-494.

Kayseri.gov. (2020, Ocak 8). Http://Www.Kayseri.Gov.Tr/Egitim-İstatistikler adresinden alındı

Keskin, S., \& Baş, M. (2015). Sosyal Medyanın Tüketici Davranışları Üzerine Etkisinin Belirlenmesi. Gazi Üniversitesi İktisadi ve İdari Bilimler Fakültesi Dergisi, 17(3), 51-69. 
Kietzmann, J., Hermkens, K., Mccarthy, I., \& Silvestre, B. (2011). Social Media? Get Serious! Understanding The Functional Building Blocks of Social Media. Business Horizons(54), 241-251.

Kıvanç, T. (2019). Sosyal Medya Bağımlılığının Sonuçları. Uluslararası Sosyal Bilimler Dergisi, 2(1), 90-101.

Kıyan, Z., \& Dikmen, E. (2019). Sosyal Medyanın Reklamcılıktaki Rolü: Instagram Üzerine Bir Araştırma. Ankara Üniversitesi İlef Dergisi, 6(1), 121-146.

Kupfer, A.-K., Vor Der Holte, N. P., Kübler, R. V., \& Hennig-Thurau, T. (2018). The Role of The Partner Brand's Social Media Power İn Brand Alliances. Journal Of Marketing, 82(3), 25-44.

Laman, I., \& Topçu, Ö. (2019). Sosyal Medyayla Birlikte Markanın Dijitalleşmesi. The Turkish Online Journal of Design, Art And Communication, 9(1), 10-21.

Marley, R. N., \& Snow, N. M. (2019). An Empirical Investigation on Social Media Users' Demand for Financial Information Distributed Via Social Media Platforms. Journal of Information Systems, 33(2), 155-175.

Mcclain, A. S. (2013). Keeping up the Kardashian Brand : Celebrity, Materialism, and Sexuality. Lanham: Lexington Books.

McQuail, D., \& Windahl, S. (1997). Kitle İletişim Modelleri. (K. Yumlu, Çev.) Ankara: İmge Kitabevi.

Metin, O. (2016). Sosyal Medyanın Siyasal Toplumsallaşmaya Etkileri: Bir Alan Araştırması? Afyon Kocatepe Üniversitesi Sosyal Bilimler Dergisi, 18(2), 221-267.

Müezzin, E. (2017). Lise Öğrencilerinde İnternet Bağımlılığının Yoksunluk, Kontrol Güçlüğü, İşlevsellikte Bozulma ve Sosyal İzolasyon Bağlamında İncelenmesi. Sakarya University Journal of Education, 7(3), 541-551.

Okay, Ş. A. (2010). MYO Öğrencilerinin İnternet Kullanım Amaçlarının İncelenmesine İlişkin Bir Araştırma. Selçuk Üniversitesi Sosyal Bilimler Enstitüsü Dergisi(23), 283-296.

Oktuğ, M. (2013). Türkiye'de Alkol Reklamlarına İlişkin Düzenlemelerin Medya Ortamındaki Yansımaları. Elektronik Sosyal Bilimler Dergisi, 12(43), 287-305.

Onat, F. (2010). Bir Halkla İlişkiler Uygulama Alanı Olarak Sosyal Medya Kullanımı: Sivil Toplum Örgütleri Üzerine Bir İnceleme. İletişim Kuram ve Araştırma Dergisi(31), 103121.

Onat, F., \& Okmeydan, C. (2015). Politik Halkla İlişkilerde Sosyal Medya Kullanımı: 30 Mart 2014 Yerel Seçimleri Ve 10 Ağustos 2014 Cumhurbaşkanlığı Seçimleri. Akdeniz İletişim(23), 79-95.

Onurlubaş, E., Öztürk, D., \& Çetin, O. (2016). Sosyal Medyada Pazarlama Algısının Faktör Analiziyle İncelenmesi. Dicle Üniversitesi Sosyal Bilimler Enstitüsü Dergisi, 8(16), 233254.

Ordenes, F. V., G. D., Ludwig, S., Ruyter, K. D., Mahr, D., \& Wetzels, M. (2019). Cutting Through Content Clutter: How Speech and Image Acts Drive Consumer Sharing of Social Media Brand Messages. Journal of Consumer Research, 45(5), 988-1012.

Özdemir, S., \& Usta, E. (2007). İlköğretim Sınıf Öğretmenliği Öğrencilerinin İnternet Kullanım Amaçlarının İncelenmesine İlişkin Bir Araştırma. Türkiye Sosyal Araştırmalar Dergisi(3), 91-110.

Öze, N. (2017). Toplumsal Kültür Haline Gelen Sosyal Medya Kullanımı ve Stratejik Pazarlama İletişimi Aracı Olarak Halkla İlişkilerin Diyalektiği. The Turkish Online Journal of Design, art And Communication, 7(2), 203-212. 
Özgezmez, Ö., \& Denktaş, G. (2017). Kruvaziyer İşletmelerin Sosyal Medyadaki Reklamları ile İlgili Tüketici Algılarının İncelenmesine Yönelik Bir Çalışma. Dokuz Eylül Üniversitesi Denizcilik Fakültesi Dergisi(UDTS Özel Sayıs1), 137-158.

Prorokova, T., \& Tal, N. (2018). Cultures Of War İ Graphic Novels : Violence, Trauma, And Memory. New Brunswick, New Jersey: Rutgers University Press.

Rosengren, K. E. (1974). Uses and Gratifications: A Paradigm Outlined. J. Blumle, \& E. Katz içinde, The Uses of Mass Communications: Current Perspectives on Gratification Research (s. 269-286). Beverly Hills, CA: SAGE.

Sabuncuoğlu, A., \& Gülay, G. (2014). Sosyal Medyadaki Yeni Kanaat Önderlerinin Birer Reklam Aracı Olarak Kullanımı: Twitter Fenomenleri Üzerine Bir Araştırma. İletişim Kuram ve Araştırma Dergisi(38), 1-23.

Sangeetha, N., \& Vanitha, J. (2019). A Study on The Impact of Electronic Media in Relation to Social Awareness Among High School Students in Coimbatore District. Online Submission, 7(3), 16-25.

Sarsar, F., Başbay, M., \& Başbay, A. (2015). Öğrenme-Öğretme Sürecinde Sosyal Medya Kullanımı. Mersin Üniversitesi Ĕ̈itim Fakültesi Dergisi, 11(2), 418-131.

Satan, A. (2013). The Factors Influencing The Internet Addiction of Secondary Education Students. Eurasian Journal of Educational Research, 53(A), 131-148.

Scholz, J., \& Smith, A. N. (2019). Branding in The Age of Social Media Firestorms: How to Create Brand Value By Fighting Back Online. Journal Of Marketing Management, 35(11/12), 1100-1134.

Sevim, N. (2018). Çevrimiçi E-Müşteri Sadakatinin Oluşumunda E-Hizmet Kalitesi, E-Güven ve E-Tatminin Etkisi. Business And Management Studies: An International Journal, 6(1), 107-127.

Shafi, R. M., Nakonezny, P. A., Romanowicz, M., Nandakumar, A. L., Suarez, L., \& Croarkin, P. E. (2019). The Differential Impact Of Social Media Use on Middle and High School Students: A Retrospective Study. Journal of Child And Adolescent Psychopharmacology, 29(10), 746-752.

Söylemez, N., \& Oral, B. (2018). Öğretmen Adaylarının Sosyal Medya Ortamlarını Kullanma Durumlarına Göre Çok Kültürlü Eğitime İlişkin Görüşleri: Türkiye Örneği. Elektronik Sosyal Bilimler Dergisi, 17(68), 1745-1764.

Süar, A. (2017). Sosyal Medyanın Geleneksel Reklam Araçlarına Göre Hedef Kitle Belirlemedeki Avantajları. Ajit-E: Bilişim Teknolojileri Online Dergisi, 8(28), 21-44.

Şahin, E., \& Dündar, M. (2019). Sosyal A ̆g ve Sosyal Medya Platformları Üzerinde Yürütülen Viral Pazarlama Faaliyetlerinin Tüketici Davranış1 Üzerindeki Etkisi: İstanbul İli Örneği. Selçuk Üniversitesi Sosyal Bilimler Meslek Yüksekokulu Dergisi, 22(1), 143-160.

Şener, G., Öğün, P., \& Akyıldız, F. (2015). Türkiye'de Sosyal Medyanın Siyasi Katılıma Etkileri. Folklor/Edebiyat, 21(83), 75-98.

Taylan, H., \& Işık, M. (2015). Sakarya'da Ortaokul ve Lise Öğrencilerinde İnternet Bağımlılı̆̆ı. Turkish Studies, 5(1), 855-874.

Tokatlı, M., Özbükerci, İ., Günay, N., \& Vural, B. (2017). Kurumsal İtibarın Sosyal Medya Üzerinden Aktarımı: Sektör Liderlerinin Twitter Yönetimi Üzerine Bir Araştırma. Gümüşhane Üniversitesi İletişim Fakültesi Elektronik Dergisi, 5(1), 34-57. 
Toker, H., Erdem, S., \& Özşarlak, P. (2017). 2015 Haziran ve Kasım Seçimlerinde Siyasal Eğilim: Yeni Bir Kamuoyu Ölçümleme Aracı Olarak Twitter. Erciyes Illetişim Dergisi, 5(1), 96117.

Topal, M., \& Akgün, Ö. (2015). Eğitim Fakültesinde Okuyan Öğretmen Adaylarının Eğitim Amaçlı İnternet Kullanımı Öz-Yeterlik Algılarının İncelenmesi: Sakarya Üniversitesi Örneği. Kastamonu Üniversitesi Kastamonu Eğitim Dergisi, 23(1), 343-364.

Toruk, İ. (2008). Üniversite Gençliğinin Medya Kullanma Alışkanlıkları Üzerine Bir Analiz. Selçuk Üniversitesi Sosyal Bilimler Enstitüsü Dergisi(19), 475-488.

Torun, E. (2017). Tüketici Satın Alma Davranışları Üzerinde İnternet ve Sosyal Medyanın Yeri ve Önemi. Elektronik Sosyal Bilimler Dergisi, 16(62), 955-970.

Tuğrul, T., Doğan, E., \& Çavuşoğlu, L. (2017). Pazarlama Alanındaki Sosyal Medya Konulu Bilimsel Çalışmalar Üzerine Keşifsel Bir Araştırma. Tüketici ve Tüketim Araştırmaları Dergisi, 9(2), 189-220.

Tuik.gov. (2019, Ocak 1). Http://Www.Tuik.Gov.Tr/Pretablo.Do?Alt_İd=1028 Erişim adresinden alınd1

Tuzcu, N., Özdemir, Ş., \& Baysal, H. (2018). Yerel Firmaların Markalama Sürecinde Dijital Reklamcılık Deneyimi: Vavin Örneği. Akdeniz İletişim(29. Özel Sayıs1), 374-392.

Usta, E. (2015). Sanal Ortamlarda Bireylerin Güvenirliğinininternet Bağımlılık Durumlarına Göre İncelenmesi. Eğitim Teknolojisi Kuram ve Uygulama, 5(2), 107-125.

Ustakara, F., \& Türkoğlu, E. (2015). Kuşağının Bir Gözetim Mekanizması Olarak Sosyal Ağlar Üzerine Alg1s1: Gaziantep Üniversitesi Araştırması. Turkish Studies, 10(10), 939-958.

Uyanık, M., \& Yükselen, C. (2019). Pazar Odaklılık ve Pazarlama Yeteneklerinin İşletmelerin Pazarlama Performansına Etkisi, İso 1000 Grubunda Bir Araştırma. Işsletme Araştırmaları Dergisi, 11(2), 1247-1261.

Voorveld, H. A., Van Noort, G., Muntinga, D. G., \& Bronner, F. (2018). Engagement With Social Media and Social Media Advertising: The Differentiating Role off Platform Type. Journal of Advertising, 47(1), 38-54.

Yılmaz, C., \& Tümtürk, A. (2015). İnternet Üzerinden Alışveriş Niyetini Etkileyen Faktörlerin Genişletilmiş Teknoloji Kabul Modeli Kullanarak İncelenmesi ve Bir Model Önerisi. Yönetim ve Ekonomi: Celal Bayar Üniversitesi İktisadi ve İdari Bilimler Fakültesi Dergisi, 22(2), 355-384.

Yolal, M., \& Kozak, R. (2008). Bilgiye Erişim Aracı Olarak Öğrencilerin İnternete Yaklaşımı. Dumlupınar Üniversitesi Sosyal Bilimler Dergisi(20), 115-128. 